\title{
32. SEISMIC MODELING AND PALEOCEANOGRAPHY AT DEEP SEA DRILLING PROJECT SITE 574 1
}

\author{
Larry A. Mayer, Department of Oceanography, Dalhousie University, Halifax, Nova Scotia \\ Thomas H. Shipley, University of Texas Institute of Geophysics \\ Fritz Theyer, Hawaii Institute of Geophysics, University of Hawaii \\ Roy H. Wilkens, Department of Earth, Atmospheric and Planetary Sciences, Massachusetts Institute of Technology \\ and \\ Edward L. Winterer, Scripps Institution of Oceanography ${ }^{2}$
}

\begin{abstract}
The analysis of high-resolution watergun seismic profiles collected in support of DSDP Leg 85 drilling reveals several major, regionally traceable reflectors that can be correlated over more than $360,000 \mathrm{~km}^{2}$ in the central equatorial Pacific. Synthetic seismograms generated from shipboard physical property measurements (carefully corrected to in situ values) for DSDP Site 574 show excellent agreement with the field records; the agreement suggests that the traveltimeto-depth conversion is accurate and permits the precise $( \pm 5 \mathrm{~m})$ location of reflectors in the cored section. The reflectors can be dated ( $\pm 0.5 \mathrm{Ma}$ ) as follows: Orange, 21.5 to $22.5 \mathrm{Ma}$; Yellow, 20.5 to $21.5 \mathrm{Ma}$; Lavender, 16 to $17 \mathrm{Ma}$; Red, 13.5 to $14.5 \mathrm{Ma}$; Purple, 11 to $12 \mathrm{Ma}$; Brown, 7 to $8 \mathrm{Ma}$; and Green, 3 to $4 \mathrm{Ma}$. Similar analyses at the other Leg 85 sites result in identical ages. The reflectors are thus time surfaces; this chapter relates them to major paleoceanographic events and changes in the relative sea-level curve. The Orange and Yellow reflectors are associated with a marked increase in $\delta^{13} \mathrm{C}$, a major change in planktonic foraminiferal assemblages, the development of the deep Circum-Antarctic Current, and the establishment of steep thermal gradients between tropical and polar regions. This reorganization of the oceanic circulation system was probably a response to the opening of the Drake Passage, and it resulted in changes in the chemistry of tropical Pacific waters that caused the induration (and thus impedance contrasts) associated with these reflectors.

The Lavender reflector is associated with a large carbonate minimum, the "Chron 16 carbon shift," a widespread hiatus (NH2), major eustatic sea-level fluctuations, and a significant increase in silica deposition in the Pacific. It is not associated with ${ }^{18} \mathrm{O}$ enrichment or climatic cooling. We conclude that this event represents an intensification in Antarctic Bottom Water (AABW) circulation and the partitioning of silica between the Atlantic and the Pacific, caused by the introduction of North Atlantic Deep Water (NADW) in response to paleobathymetric and tectonic events. The Red reflector is associated with a subdued carbonate minimum, a widespread hiatus (NH3), a sea-level drop, significant changes in microfossil assemblages, and a major increase in $\delta^{18} \mathrm{O}$ that has been linked with the buildup of Antarctic ice. Detailed isotopic analyses reveal that this isotopic shift occurred within an interval of $30,000 \mathrm{yr}$. and precisely at the depth of the Red reflector.

The Purple reflector is associated with an extremely large carbonate minimum, a change in the style of carbonate deposition in the Pacific, a major lithologic boundary, a widespread hiatus (NH4), an increase in the provincialism between low and high latitudes in all planktonic microfossil assemblages, an apparent fall in eustatic sea level, an enrichment in $\delta^{18} \mathrm{O}$, and a major North Atlantic reflector interpreted as representing an intensification of North Atlantic bottom-water circulation.

The Brown reflector is roughly associated with a small carbonate minimum, an enrichment in $\delta^{18} \mathrm{O}$, the late Miocene $\delta^{13} \mathrm{C}$ depletion, a drop in the relative sea-level curve, and major faunal changes.

The Green reflector is associated with a large carbonate minimum, an enrichment in $\delta^{18} \mathrm{O}$, a major western North Atlantic erosional event, and a widespread eastern Atlantic seismic reflector. The bulk of evidence supports correlation with the onset of Northern Hemisphere glaciation, but detailed isotopic analyses indicate that this isotopic event may be linked to the establishment of colder bottom waters without major ice-sheet development.

Several types of reflectors have been identified. The reflectors in the older section result from diagenetic effects; the regionally correlatable reflectors are associated with global events. In the younger (post-18 Ma) section, local reflectors are characterized by velocity contrasts, whereas regional reflectors are associated with density contrasts caused by carbonate minima. Two modes of generation of carbonate minima (and thus of reflectors) spanning the equatorial Pacific are (1) the intensification of AABW without the concurrent intensification of NADW and so without fractionation of silica between the Atlantic and the Pacific; this mode results in the less extreme carbonate minima; and (2) the intensification of AABW in response to the intensification of NADW; this mode results in extreme carbonate minima and a correlation of equatorial Pacific reflectors with North Atlantic events.
\end{abstract}

\footnotetext{
${ }^{1}$ Mayer, L., Theyer, F., et al., Init. Repts. DSDP, 85: Washington (U.S. Govt. Printing Office). This work was supported by ONR contract N00014-82-K-0625 to L.M. and by the Natural Sciences and Engineering Council of Canada. F.T.'s research was supported by NSF grants OCE 81-17997 and OCE 85-04146. T.S. was supported by N00014-81-K-0728.

2 Addresses: (Mayer) Dalhousie University, Halifax, Nova Scotia, Canada B3H 4J1; (Shipley) University of Texas, Institute of Geophysics, Austin, TX 78712; (Theyer, present address) Department of Geological Sciences, University of Southern California, University Park, Los Angeles, CA 90089; (Wilkens) Department of Earth, Atmospheric and Planetary Sciences, Massachusetts Institute of Technology, Cambridge, MA 02139; (Winterer) Scripps Institution of Oceanography, University of California at San Diego, La Jolla, CA 92093.
}

\section{INTRODUCTION}

The fertile waters of the central equatorial Pacific have produced a thick section of biogenic sediment that is an extremely sensitive indicator of the interplay among tectonism, circulation, productivity, and diagenesis. Studies of equatorial Pacific piston cores (e.g., Arrhenius, 1952; Berger, 1973; CLIMAP, 1976; Hays et al., 1969; 
Luz, 1973; Shackleton and Opdyke, 1973, 1976) have resulted in a fairly detailed picture of the distribution of modern oceanographic parameters and the paleoceanography of the past 2 to $3 \mathrm{~m}$.y. Deep-sea drilling in the region has produced an intriguing record of paleoceanographic change for the past 40 m.y. (e.g., Tracey, Sutton, et al., 1971; Hays et al., 1972, pp. 43-61; van Andel and Heath, 1973; Winterer, 1973; van Andel et al., 1975; Leinen, 1979; Kennett, in press), but truly detailed studies on this older material have been frustrated by incomplete coring and by core disturbance. Deep Sea Drilling Project Leg 85, however, using the hydraulic piston corer (HPC) in the upper, unconsolidated part of the section and rotary coring in the deeper parts of the section, returned to the central equatorial Pacific and collected nearly complete and relatively undisturbed sedimentary records of the past 40 m.y. (site chapters, this volume). The Leg 85 coring has provided a wealth of material that is ideal for studies of fine-scale biostratigraphy (Barron et al.; Bukry; Labracherie; Jarvis and Tocher; all this volume), paleomagnetism (Weinreich and Theyer, this volume), carbonates (Pisias and Prell, this volume), isotopes (Pisias and Shackleton; Miller and Thomas; Vincent and Killingley; all this volume), and physical properties (Wilkens and Handyside, this volume). In addition, the Leg 85 sites were the first surveyed for DSDP with the relatively new high-resolution watergun seismic source (Shipley and Winterer, this volume). The collection of detailed physical and stratigraphic data in conjunction with high-quality, digital, high-resolution seismic profiles presents a unique opportunity to investigate the origin of the seismic record in this region by using quantitative modeling techniques (synthetic seismograms) and to evaluate the potential of equatorial $\mathrm{Pa}$ cific seismic stratigraphy as a paleoceanographic tool.

For most of the relatively short (60-yr.) history of seismic exploration, reflection profiling has had an invaluable but rather limited role in the exploration of the subsurface. Numerous constraints (e.g., resolution limitations due to narrow bandwidth and data degradation due to geometric or instrumental artifacts and small dynamic recording and display ranges) limited the role of the reflection profile to that of a structural or geometric tool. The profile yielded information on arrival time and dip (and therefore structural styles and faulting) but little more. Recently, however, with rapid advancement in the development of seismic sources and data acquisition and processing techniques, and with the pioneering work of Vail et al. (1977) and Brown and Fisher (1977), we have begun to extract detailed and direct stratigraphic information from the seismic record. With the derivation of stratigraphic information from the seismic record, we are approaching the true potential of reflection profiling - that is, the rapid and remote determination of the exact nature (lithologic parameters, sediment facies, depositional environment) of the subsurface material, and, from this, the determination of the geologic history of a region.

The success of the application of seismic stratigraphic concepts to petroleum exploration problems on land and in shallow water results, in part, from the numerous boreholes and large amount of high-quality seismic data available. The scientist working on deep-sea problems, however, is often faced with a few widely spaced DSDP holes and limited seismic data. Nonetheless, significant progress has been made in deep-sea seismic stratigraphy. This is particularly true for the western North Atlantic, where the analysis of a fair number of multichannel seismic (MCS) lines and numerous DSDP sites has resulted in an evolving stratigraphic framework (Sheridan et al., 1983; Shipley et al., 1978; Tucholke, 1979; Tucholke and Mountain, 1979). Shipley (1983) used seismic modeling and DSDP sites in this region in an attempt to reconcile discrepancies in well-hole seismic correlations. A careful study of the problem led him to conclude that the uncertainties associated with incomplete coring and core disturbance made the development of a single unique correlation between existing drill-hole and seismic data impossible, however.

In the central equatorial Pacific, unlike the western North Atlantic, no MCS data have been collected. Most of the data collected in this region have been analog, single-channel airgun data that can be analyzed only in terms of seismic character (e.g., transparent, opaque, or reverberant) and yield little direct stratigraphic information (Ewing et al., 1968; Houtz and Ludwig, 1979). Recently, Shipley et al. (1983), using digital airgun data, have demonstrated the potential of the application of seismic stratigraphic techniques to the deep-sea environment (Hess Rise); but detailed correlations of their data were impossible because of the very limited core recovery in the region. Despite these limitations, Winterer, Riedel, et al. (1971), Winterer et al. (1974), Schlanger and Douglas (1974), Berger et al. (1977), Berger and Mayer (1978), and others have suggested that the seismic record of equatorial Pacific sediments, which are biogenic in origin and sensitive to changes in the chemistry of the oceans, might hold important paleoceanographic information. Mayer (1979a), using 10-m-long piston cores and high-resolution 4-kHz seismic profiles, demonstrated that, for at least the upper $10 \mathrm{~m}$ of equatorial Pacific sediments, contrasts in acoustic impedance can be directly related to glacial/interglacial cycles. When these impedance contrasts were compared with the $4-\mathrm{kHz}$ seismic record, however, it became clear that the closely spaced reflections visible in the seismic profile were not direct representations of the impedance contrasts in the sediment column but, rather, interference patterns resulting from complex interactions between closely spaced impedance boundaries and the seismic wavelet (Mayer, 1979b). Thus, even a $4-\mathrm{kHz}$ profiling system with resolution of less than $1 \mathrm{~m}$ cannot resolve the discrete stratigraphic discontinuities that are ultimately responsible for seismic reflections. An understanding of the implications of this result is critical to the proper application of the principles of seismic stratigraphy to deep-sea sediments.

It is fundamental to the stratigraphic interpretation of seismic data that the seismic information be expressed in geologic terms. The accurate transformation of seismic data into geologic information requires an understanding of the limitations of the techniques involved, particularly, as just mentioned, the limitations in resolu- 
tion due to the characteristics of the seismic wavelet. The principal mechanism by which we gain insight into the nature of this transformation is the synthetic seismogram. Varying degrees of complexity can be applied to the generation of synthetic seismograms, but in essence the technique models the interaction between a seismic wavelet and a given well-constrained geological model. If we have an accurate representation of the seismic source wavelet and an accurate and detailed picture of subsurface geologic variations, the synthetic seismogram should provide a record of their interactions and allow us to address the origin and geologic significance of the seismic reflections with some confidence.

In this chapter we use the detailed stratigraphic and physical property results of Leg 85 and the high-resolution seismic data collected during the Leg 85 site surveys to evaluate the potential of seismic stratigraphic work in the central equatorial Pacific. To do this, we briefly examine the nature of the seismic section in the region, discuss the approach to and results of seismic modeling at DSDP Site 574, and attempt to infer the paleoceanographic significance of the major regional seismic horizons.

\section{THE SEISMIC REFLECTION DATA}

\section{Objectives and Criteria}

The seismic reflection data presented here were collected aboard the Thomas Washington as part of a sitesurvey program in support of Leg 85 drilling (Shipley et al., this volume). The site surveys were undertaken to acquire high-resolution records of seafloor bathymetry and the subsurface seismic section. Pelagic carbonate sequences are usually highly reflective, and the reflectors show substantial lateral continuity. Signal-to-noise ratios are thus often not critical in this sediment type (Berger et al., 1977; Schlanger and Douglas, 1974; Winterer et al., 1974). These factors combine to make most conventional seismic data from these environments appear to be of high quality and to be related to the geology in a simple manner. As discussed earlier, however, Mayer (1979b) has demonstrated that in equatorial carbonates, downsection variations in acoustic properties occur more rapidly than conventional sound sources can resolve.

\section{EQUIPMENT AND METHODS}

With resolution, penetration, cost, and safety as criteria, we examined the sound sources available for underway geophysical studies. We identified the Seismic Systems 80-in. ${ }^{3}$ (1.3-1), 2000-psi (136-atm.) watergun as a good compromise between power and bandwidth. A farfield source signature for the gun at our usual towing depth of $3 \mathrm{~m}$ shows the short duration of the pulse, which translates to a fairly broad bandwidth (Figs. 1A, B). A prominent "precursor" (a long-duration, low-amplitude, early-arriving portion of this pulse) is the only significant aberration. We tried several band-limiting filters and deconvolution routines to remove this precursor. We were most successful using Digicon's DECONS program, which calculates a deconvolution filter so that the output is a minimum-phase pulse of bandwidth similar to that of the original data. This filter, when applied to the original source-signature pulse, substantially reduced the precursor as well as other ringing in the pulse (Fig. 1C). Since we only recorded source signatures at one site, the application of the filter to all the field data is suspect, even though we tried to keep the source, receiver, and towing arrangements as constant as possible throughout the
A

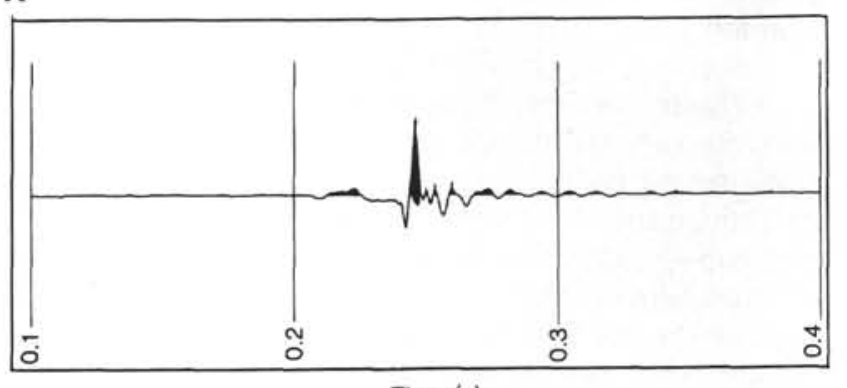

B

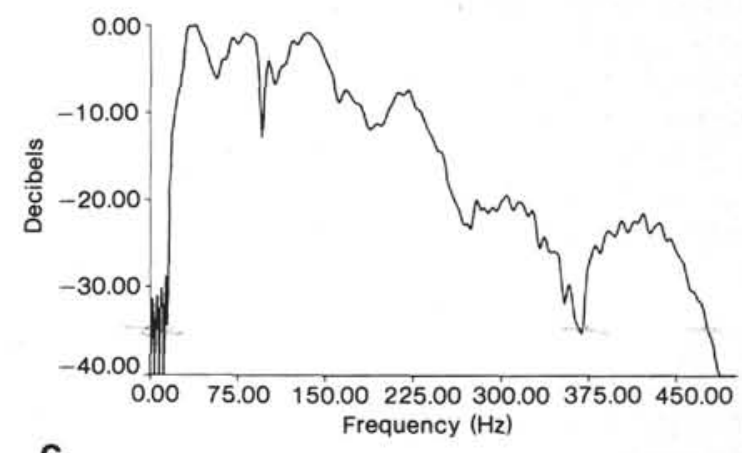

C

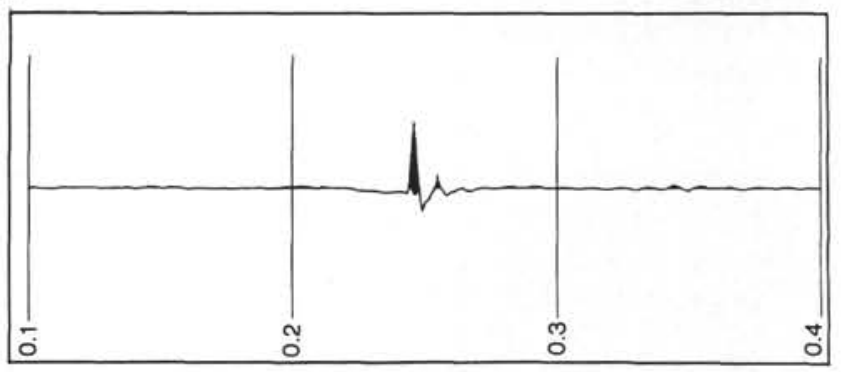

Time (s)

Figure 1. Source signatures for SIO 80 -in. ${ }^{3}$ watergun. A. Raw source signature. B. Spectrum of raw source signature. C. Source signature with DECONS operator applied.

cruise. Even so, the use of the minimum-phase filter at the other sites does appear to be equally effective.

The streamer we used for the work south of the Clipperton Fracture Zone is a Teledyne streamer with acceleration-canceling hydrophones in a linear array. The streamer was driven with a preamplifier designed at the Scripps Institution of Oceanography. The streamer depth was monitored with a calibrated depth sensor at the head of the leader. The towing depth varied between 5 and $15 \mathrm{~m}$ but remained between 6 and $10 \mathrm{~m}$ most of the time.

The analog data were first bandpass filtered $13 \mathrm{~Hz}$ to $500 \mathrm{~Hz}$ with a low cut slope of $10 \mathrm{~dB} /$ oct. and a high cut slope of $50 \mathrm{db} /$ oct. The data were then digitized at a $0.5-\mathrm{ms}$ period with a binary gain ranging scheme that gives the system about $60 \mathrm{~dB}$ of dynamic range. A 12-bit number and gain bits were then passed to the computer, and the data and gain information were recombined and then written on tape in standard SEGY 32-bit integer format.

The data used in interpretations and presented in this chapter are mostly filtered 30 to $250 \mathrm{~Hz}$ or 30 to $400 \mathrm{~Hz}$ with various filter tapers and rolloff severity. The minimum-phase filter was applied to some sections. None of the data have been amplitude normalized, windowed, or corrected for spherical divergence. These data are true amplitude, in the sense that all recording gains have been removed. For some sections, the plot amplitude was raised to enhance the later arrivals, with overdriving affecting some of the earlier strong events. Plot amplitude is strictly the multiplication factor applied to each sample; it is in no way a time- or trace-varying gain. 


\section{Characteristics of the Seismic Section in the Region Studied}

Although seismic data were collected on well over $8000 \mathrm{~km}$ of the site survey cruise, this report concentrates on the portion of the survey track that is bounded by the Clipperton Fracture Zone to the north and the Galapagos Fracture Zone to the south and forms a quadrilateral $600 \mathrm{~km}$ on a side (Fig. 2). In particular, we will discuss the seismic section in the vicinity of Site 574, which, except as otherwise noted, is characteristic of the seismic record in the region defined by this quadrilateral (Fig. 3). The profiles along this track were examined, and major, regionally traceable reflectors were identified and assigned color names. The reflectors labeled, in order of increasing traveltime (or age) are G (Green), B (Brown), P (Purple), R (Red), L (Lavender), Y (Yellow), and $\mathrm{O}$ (Orange) (Fig. 3). One other regionally traceable reflector, M (Magenta), which normally occurs between the Green and Brown reflectors, is not identifiable on this profile. All these reflectors are traceable for hundreds of kilometers both south and west of Site 574; all except the Purple and Yellow reflectors are traceable completely around the $600-\mathrm{km}$-per-side quadrilateral. The Lavender and Red reflectors, which are particularly prominent and easy to trace, are recognizable on lower-resolution airgun profiles for at least $1500 \mathrm{~km}$ west and $600 \mathrm{~km}$

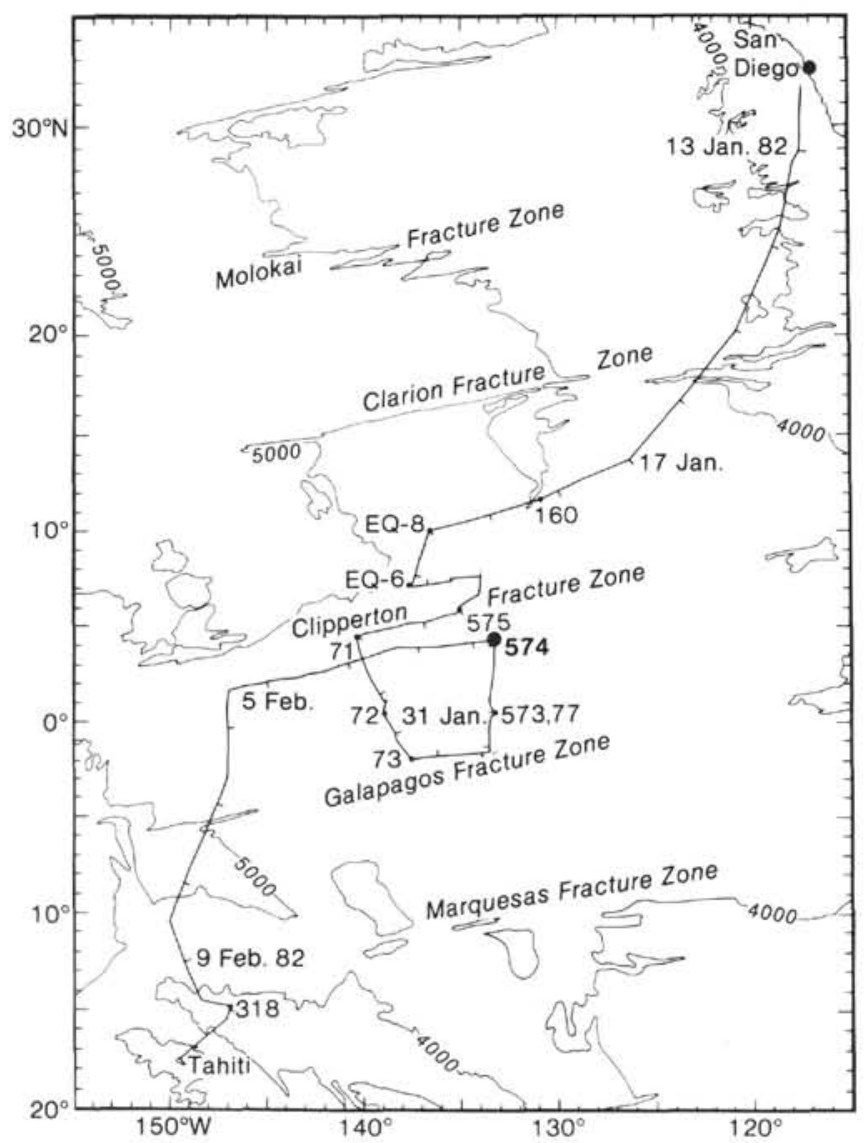

Figure 2. Ship track of the Thomas Washington for DSDP Leg 85 site surveys. east of Site 574, within the great lens of equatorial biogenic sediments. These reflectors are clearly regional and can be identified over an area of at least $20^{\circ}$ by $6^{\circ}$, or 1.6 million $\mathrm{km}^{2}$.

The seismic section in the vicinity of Site 574 shows a number of features common to records elsewhere in the equatorial sediment lens.

1. The dominant "style" or geometry of the acoustic stratigraphy is simple pelagic drape. Most reflectors are remarkably parallel to their neighbors.

2. Erosional effects (Shipley et al., this volume, figs. $9,10,13,14)$ are especially common in the younger (post-Green reflector) strata. Channels are most commonly associated with buried or exposed basement relief, and some channels take the form of partial or complete moats around hills. In some places, the effect of bottom currents is to inhibit sedimentation (bypassing) rather than to erode, and this effect is shown by the progressive convergence of reflectors; the convergence is in contrast to the clear angular truncation that characterizes the older reflectors where erosion has removed previously deposited sediments.

3. A ubiquitous feature of the profiles is the evidence of the progressive infilling and smoothing of original basement relief (Shipley et al., this volume, figs. 5, 6). The filling in of troughs occurs mostly in the early (preRed) stages of sedimentation: the acoustic reflectors between the Red and Green reflectors tend to be nearly parallel, except for thinning over buried hills.

4. Slopes between the hills and troughs, especially in the lower, pre-Red strata, commonly show mounds of acoustically chaotic sediments that we interpret as slide or slump masses (Shipley et al., this volume, figs. 5, 6, $10)$.

5. In terms of acoustic "character," that is, the relative transparency or spacing of the reflectors in various parts of the section, we see great variability in detail, but a few generalizations hold true:

A. The post-Red reflectors are generally fairly closely spaced and continuous compared with the pre-Red reflectors.

B. There is often a relatively transparent interval between the Red and Lavender reflectors.

C. Below the Lavender reflector and down to a level about $0.1 \mathrm{~s}$ above acoustic basement, the reflectors become progressively more faint and difficult to trace.

D. In the lowest $0.1 \mathrm{~s}$ above acoustic basement, the reflectors have progressively greater amplitude.

E. The top of acoustic basement is commonly difficult to pick unequivocally, in spite of the large impedance contrast at the sediment/basalt interface.

We turn now to the major, regionally traceable seismic horizons identified at Site 574; using the techniques of seismic modeling, we shall look at their origins and paleoceanographic significance.

\section{SEISMIC MODELING}

We have already discussed the importance of the synthetic seismogram in evaluating the geologic significance of seismic reflections. The two critical inputs into the synthetic seismogram are the seismic wavelet and the ge- 


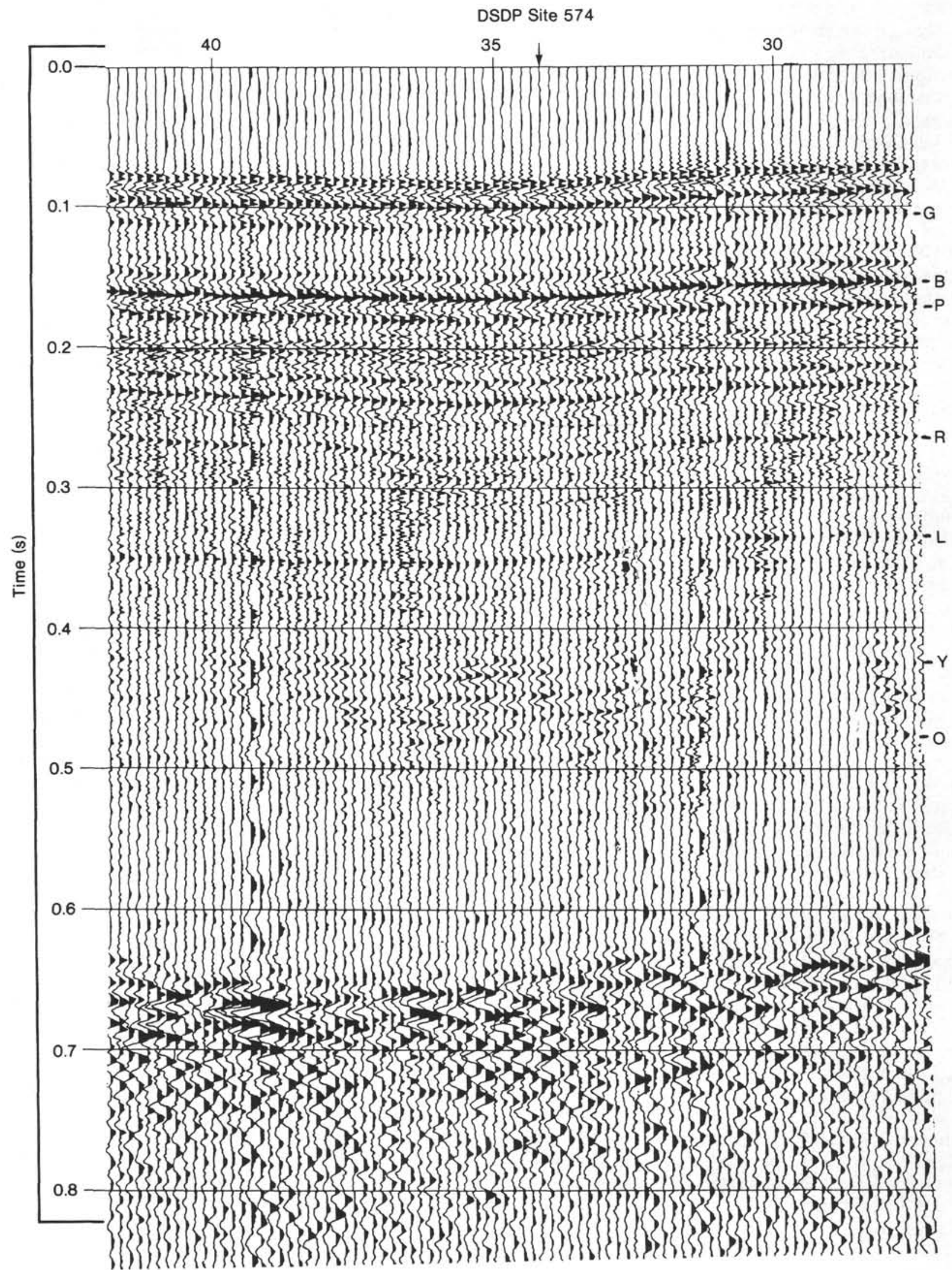

Figure 3. 80-in. ${ }^{3}$ watergun profile near DSDP Site 574. 
ologic model. The seismic wavelet used to produce the results and the field sections presented here was obtained by applying a deconvolution filter to the field-measured far-field source signature (see discussion under Seismic Reflection Data; Fig. 1).

The geologic model is the result of the shipboard physical property program. On Leg 85 , sonic velocity, saturated bulk density, porosity, water content, grain density, formation factor, thermal conductivity, and percent calcium carbonate were measured at least once per cored section (every $150 \mathrm{~cm}$ ). The techniques and details of the physical property program are discussed by Wilkens and Handyside (this volume). The sections acquired at Site 574 provided the most reliable and continuous physical property results; measurements on the second HPC hole at the site replicated the values determined on the first HPC hole almost perfectly (see Wilkens and Handyside, this volume). Because of our confidence in the quality of the measurements and in our depth control on the samples, we merged all four holes at Site 574 to produce a single data set for each property. The resulting average sample interval is less than $1 \mathrm{~m}$.

From the standpoint of seismic modeling, the most important physical properties are saturated bulk density and sonic velocity. It is the product of these two properties that results in acoustic impedance, and contrasts in acoustic impedance produce seismic reflections. The original data for saturated bulk density and sonic velocity versus depth are presented in Figure 4. Close inspection of Figure 4 reveals that saturated bulk density and velocity are not always measured at exactly the same depths. To calculate acoustic impedance, we chose to use the density data as the primary data set, and to each depth for which there was a density value we assigned the nearest velocity value. This procedure is easy to justify. First, almost all the velocity measurements were made within a few centimeters of the density measurements. Bioturbation mixes the sediment over an interval thicker than this (Berger and Heath, 1968; Berger and Killingley, 1982). Second, an examination of the downcore variation in both density and velocity reveals that for most of the section velocity does not vary significantly (less than $6 \%$ of its mean value), whereas density fluctuates by more than $25 \%$ of its mean value. Thus, most of the variation in acoustic impedance is due to the fluctuation in saturated bulk density, not velocity. The reasons for this relationship are examined in detail by Mayer (1979a, 1982).

Given a set of velocity of saturated bulk density values at the same depths below the seafloor, we now face one of the most critical and difficult steps in applying stratigraphic significance to seismic data-the transformation of sub-bottom depth information into traveltime information. All the downcore information whether biostratigraphic, magnetic, physical property, or isotopic is measured as a function of depth below the seafloor-a spatial-domain record. The seismic section, on the other hand, is a time-domain record. Therefore the correlation of seismic data with well hole data is dependent on the assumption that the conversion from traveltime to depth (or vice versa) is accurate. This assumption implies an exact knowledge of the in situ velocity versus depth function-a knowledge that is rarely available.
Sediment velocity information can be obtained in several ways. Refraction and wide-angle reflection experiments can provide interval velocities between major discontinuities, but they usually provide only a very limited number of solutions in the sediment column. In the presence of a borehole, logging and vertical seismic profiling (VSP) experiments can provide a detailed picture of the velocity-versus-depth structure of the sediment column, but unfortunately, no logging or VSP experiments were undertaken at the Leg 85 sites. A final approach is the detailed laboratory measurement of velocity on cored samples. This is customarily done on DSDP cruises, but before this information can be used for converting traveltime to depth, the laboratory measurements must be corrected to in situ values. This correction is neither straightforward nor trivial.

The magnitude of the problem can easily be seen in the following tabulation, which compares the average velocities at Site 574 computed from (1) uncorrected laboratory measurements, (2) averages of wide-angle reflection/refraction measurements made in equatorial carbonates, and (3) the ratio of basement depth (determined by drill string) to the best pick of basement traveltime.

\footnotetext{
Average velocity-laboratory measurements $1580 \mathrm{~m} / \mathrm{s}$ Average velocity-sonobuoy/refraction $\quad 1987 \mathrm{~m} / \mathrm{s}^{\mathrm{a}}$

Basement pick $(0.60 \mathrm{~s}) /$ drill-string depth to $1747 \mathrm{~m} / \mathrm{s}$ basement

Average final corrected velocities $\quad 1691 \mathrm{~m} / \mathrm{s}$

${ }^{a}$ From Johnson et al. (1978); Kroenke (1972); Winterer, Riedel, et al. (1971); Ewing et al. (1968).
}

It is clear from this tabulation that the laboratory values are 15 to $20 \%$ less than those more closely representing in situ conditions. Although there is some uncertainty in the actual pick of basement on the seismic section (Fig. 3, between 0.57 and $0.62 \mathrm{~s}$ ), the use of laboratory velocity values in a point-by-point conversion of depth to traveltime would place basement at $0.641 \mathrm{~s}$, well below a reasonable position. If we were interested only in accurately determining the average velocity in the sediment column, the division of the drill-string-determined basement depth by the best pick of traveltime to basement would suffice. We are concerned, however, with detailed correlation of the major reflections with the borehole results, so we must know the in situ velocity over small, discrete intervals.

\section{Conversion from Laboratory to in Situ Values}

When a sample is removed from a borehole and brought to laboratory conditions ( 1 atm. and approximately $25^{\circ} \mathrm{C}$ ), it is subject to changes in several conditions that will affect the measured velocity. Hamilton $(1965,1976)$ discusses four factors that must be accounted for in order to correct laboratory measurements to in situ values: (1) the change in temperature; (2) the decrease in hydrostatic pressure; (3) the decrease in porosity caused by the removal of overburden; and (4) the decrease in rigidity (intergranular locking) that results from the removal of overburden. Of these factors, the decrease in porosity caused by the removal of overburden has the 

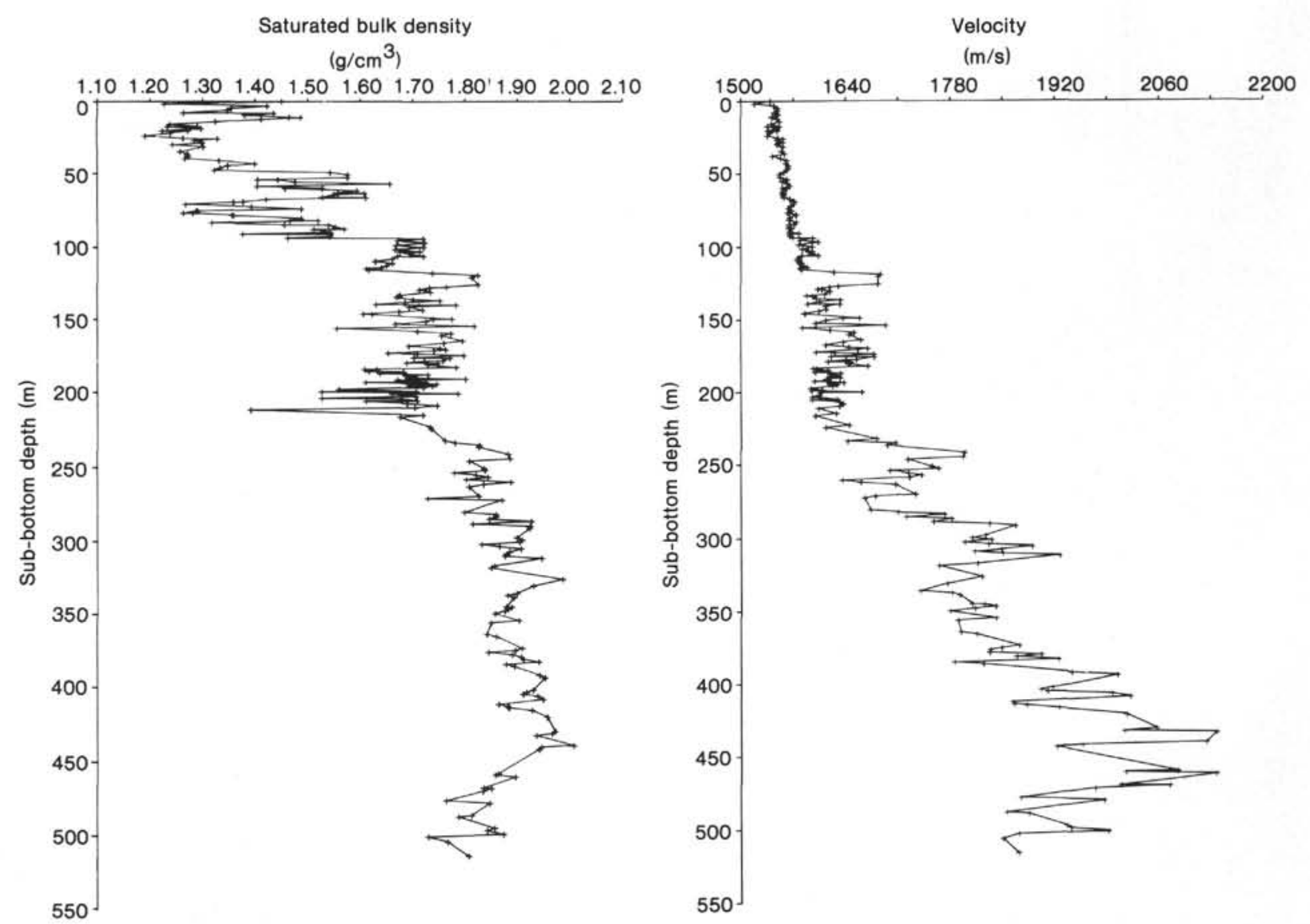

Figure 4. Laboratory-measured saturated bulk density and sonic velocity versus sub-bottom depth for DSDP Site 574.

most significant effect (Hamilton, 1976, 1979; Boyce, 1976).

\section{Rebound-Corrected Porosity/Density}

Using consolidation test data on carefully selected DSDP samples, Hamilton (1979) constructed a series of curves that predict the elastic rebound resulting from the removal of overburden pressure for each of the major deep-sea sediment types. Entering the Site 574 porosity and depth data into Hamilton's (1976) equation for deepsea carbonates results in a rebound curve that predicts the need for an approximately $5.5 \%$ reduction in porosity for the deepest Site 574 samples ( $518 \mathrm{~m}$ sub-bottom, Fig. 5). Geally and Gerard (1970) and Shipley (1983) have found that logging-derived porosity values in deep-sea carbonates closely follow Hamilton's predicted curve to depths of $700 \mathrm{~m}$, strongly supporting this correction procedure. Because of the well established linear relationship between saturated bulk density and porosity in deepsea carbonates (Fig. 6), a rebound correction can easily be applied to the saturated bulk density values measured in the laboratory.

\section{Rebound-Corrected Velocity}

Substantial empirical data have permitted the establishment of curves predicting the effect of rebound on porosity, but very few data are available for the direct - correction of velocity values. Laughton (1957) did directly measure the increase of velocity with increasing pressure on a carbonate sample, but this single data set is not sufficient to permit the derivation of general relationships. In the absence of direct measurements, we must determine the rebound-corrected velocity indirectly, from the rebound-corrected porosity. Seeking a similar correction, Boyce (1976) and Shipley (1983) plotted laboratory porosity against laboratory velocity and used a graphic offset to estimate in situ velocities. We have a much more continuous data set than either Boyce or Shipley, and given the clearly nonlinear relationship between laboratory porosity and velocity (Fig. 7), we chose to use a series of multiple linear regressions to attempt to establish a means of predicting velocity from porosity. We tested our prediction scheme by comparing the measured laboratory velocities against the velocities predicted by our regression equations, and we found that by dividing the sediment column into four discrete sections and using a third-order regression in each section we were able to duplicate the original laboratory velocity curve accurately (Fig. 8). The need to divide the sediment column into discrete sections and to establish individual correlations between porosity and velocity for each section suggests that different processes are at work in each depth zone, and that this sort of correlation may provide a way to examine these processes. For example, between 450 and $510 \mathrm{~m}$, porosity increases but velocity does not decrease. This anomalous relationship probably indicates an increase in silica content and the onset of cementation. The ramifications of this finding will be 


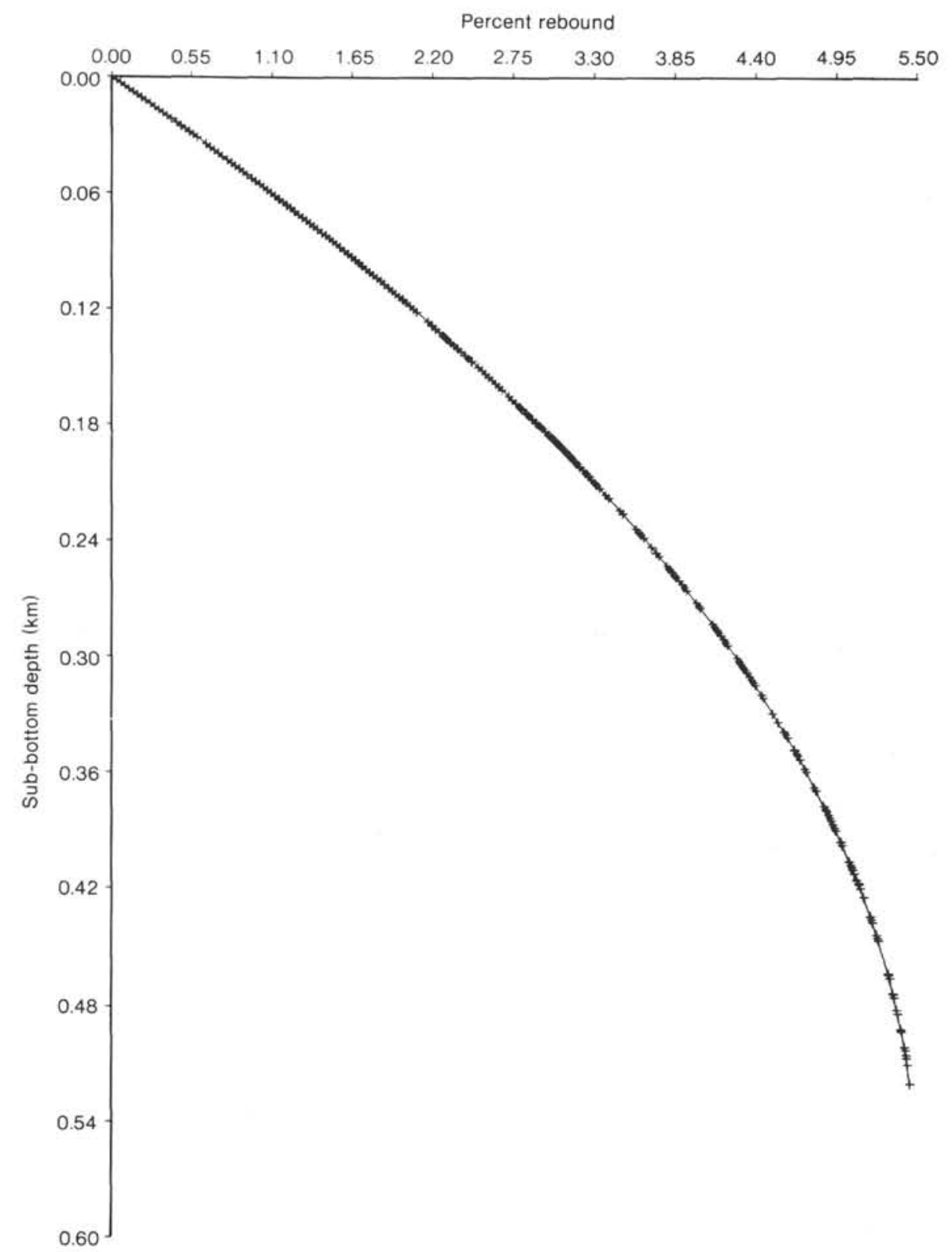

Figure 5. Calculated percent porosity rebound versus sub-bottom depth for DSDP Site 574.

discussed elsewhere. With a way to accurately predict laboratory velocity from laboratory porosity, we can use rebound-corrected porosities to calculate rebound-corrected velocities.

\section{Corrections for Temperature and Pressure}

To correct for the effects of temperature and hydrostatic pressure, profiles of in situ temperature and pressure must be established. To estimate hydrostatic pressure, we multiplied an assumed seawater density of 1.06 $\mathrm{g} / \mathrm{cm}^{3}$ by the depth below sea level. To estimate the temperature profile, we used the results of detailed heatflow studies in the region (Crowe, 1981), which show an average heat flow of $1.76 \mathrm{cal} / \mathrm{cm}^{2} \mathrm{~s} \times 10^{-6}$ and an average conductivity of $2.08 \mathrm{cal} / \mathrm{cm} \mathrm{s}^{\circ} \mathrm{C} \times 10^{-3}$. We established a temperature profile by using these values as initial points and using Hamilton's (1979) generalized curve for conductivity versus depth in deep-sea carbonates. Although temperature and pressure affect both the liquid and solid phases of the saturated sediment system, Boyce (1976), citing Hughes and Cross's (1951) experiments on wet and dry limestone, suggests that the variation in velocity of the solid end-member (calcite) is less than $1 \%$ for the pressure and temperature ranges that exist at Site 574. We therefore assumed that the in situ velocity of the solid end-member was the same as that measured in the laboratory. The variations in velocity with changes in the temperature and pressure of the liquid phase (seawater), on the other hand, are significant, but they are well documented (U.S. Naval Oceanographic Office, 1962; Wilson, 1960) and are easy to calculate. Given the rebound-corrected velocities and the velocity of the liquid and solid end-members at laboratory and in situ conditions, we then calculated the in situ velocity by using the 


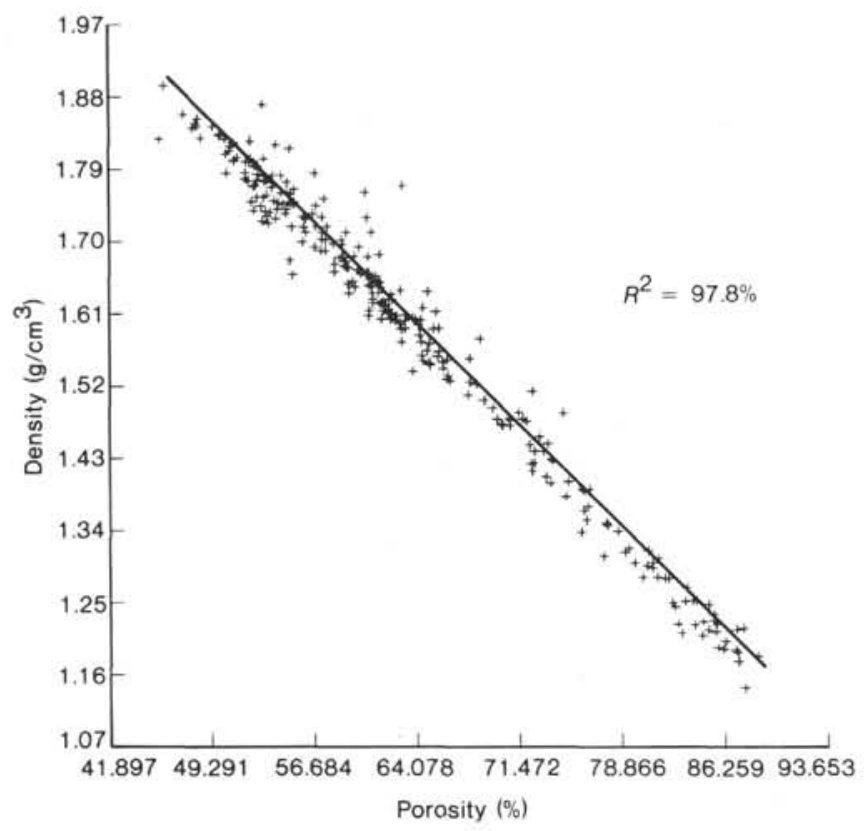

Figure 6. Regression of saturated bulk density against porosity for DSDP Site 574. $R^{2}=$ correlation coefficient.

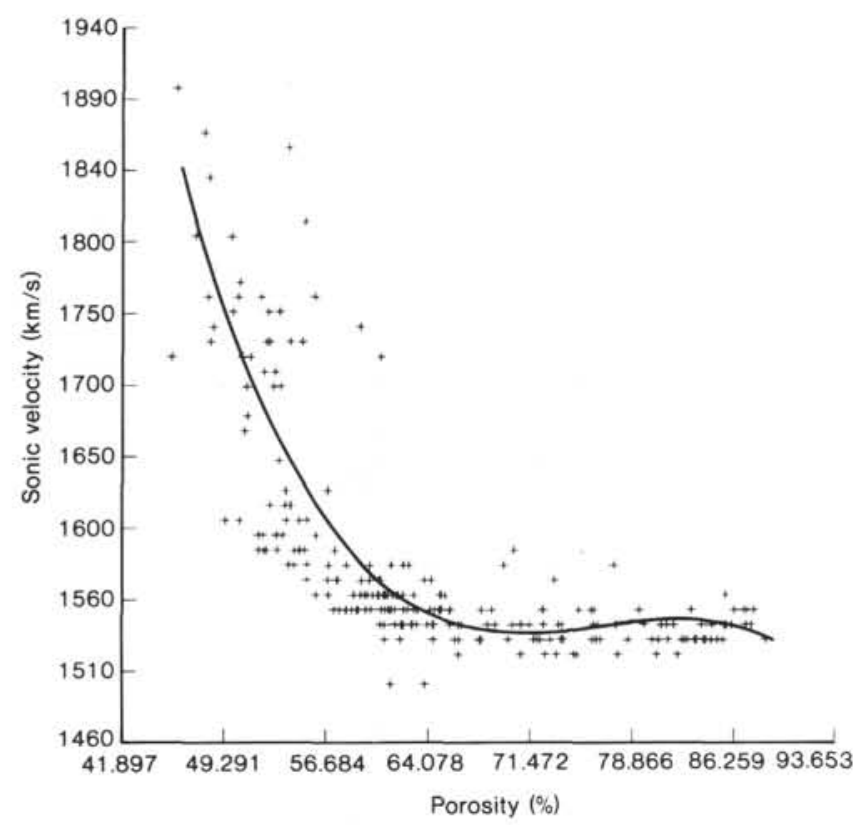

Figure 7. Regression of porosity against sonic velocity for DSDP Site 574. Solid curve is a third-order regression line.

technique of Boyce (1976; Fig. 9). The resulting velocities are corrected for all the factors discussed by Hamilton $(1965,1976)$ except the decrease in rigidity caused by the removal of overburden. The evidence available at present is insufficient to permit a correction for this factor to be derived empirically, so our in situ velocities are minimum values. Calculations made using these velocities, however, place basement at $0.611 \mathrm{~s}$ (Fig. 10), which is well within the uncertainty of the basement pick and which indicates that the unaccounted-for rigidity factor is probably of minor significance.

\section{Calculation of Synthetic Seismograms}

The corrected velocities and saturated bulk densities can then be used to calculate acoustic impedance (the product of velocity and density) as a function of traveltime (Fig. 10). The impedance curve shows numerous high-frequency fluctuations with several major offsets; the origin of the impedance fluctuations will be discussed in detail later. The parameter of key importance to seismic profiling is the reflection coefficient-the ratio of the amplitude of the reflected wave to that of the incident wave. For normal incidence (the situation with which we are concerned), the reflection coefficient can be expressed strictly in terms of the impedances of the media involved. After the impedance curve is interpolated and resampled (at a sample interval equivalent to that at which the source signature was sampled), a reflectioncoefficient log (Fig. 11) can easily be computed. As is typical of deep-sea carbonates, the reflection-coefficient structure is extremely complicated and has much fine structure beyond the resolution of conventional profiling systems. This reflection-coefficient log is convolved with the selected source signatures (the field-measured source signatures with and without a deconvolution filter applied to them) to generate a synthetic seismogram (Fig. 12). The synthetic seismogram is then filtered with the same bandpass filter as that used for the field data, and it is displayed on a similar scale for comparison. The modeling algorithm used to generate these synthetic seismograms assumes that we are dealing with normally incident plane waves, that no energy is lost to attenuation, and that interbed multiples play no significant role. The validity of these assumptions will be tested by comparing the synthetic seismogram with the field record.

Synthetic seismograms were generated by using both the raw source signature and a deconvolved operator (Fig. 12). To increase the signal-to-noise ratio and reduce shot-to-shot variations, three trace mixes were also calculated. Comparison of the synthetic with the field data (Fig. 13) shows generally good agreement for the major reflectors. The major differences are in the shape and amplitude of the reflections (e.g., Purple, Brown, and Red appear as several positive amplitude peaks in the synthetic and as only a single peak in the field data). This is not very surprising in view of the extremely short wavelength variation in the reflection-coefficient $\log$ (Fig. 11) and the number of uncertainties associated with this sort of comparison. As discussed earlier, and as demonstrated by Mayer (1979b), much of the reflection profile (and the synthetic profile) in deep-sea carbonates is an interference composite; subtle changes in the source function can have significant effects on the type of interference (e.g., compare the Green reflector in the raw source-function synthetic with that in the deconvolved source-function synthetic). More important, the slightest change or inaccuracy in the determination of the reflection-coefficient log will have a similar effect, and the absence of the inclusion of internal multiples and attenuation certainly degrades the synthetic. Although we believe that the low reflection coefficients 


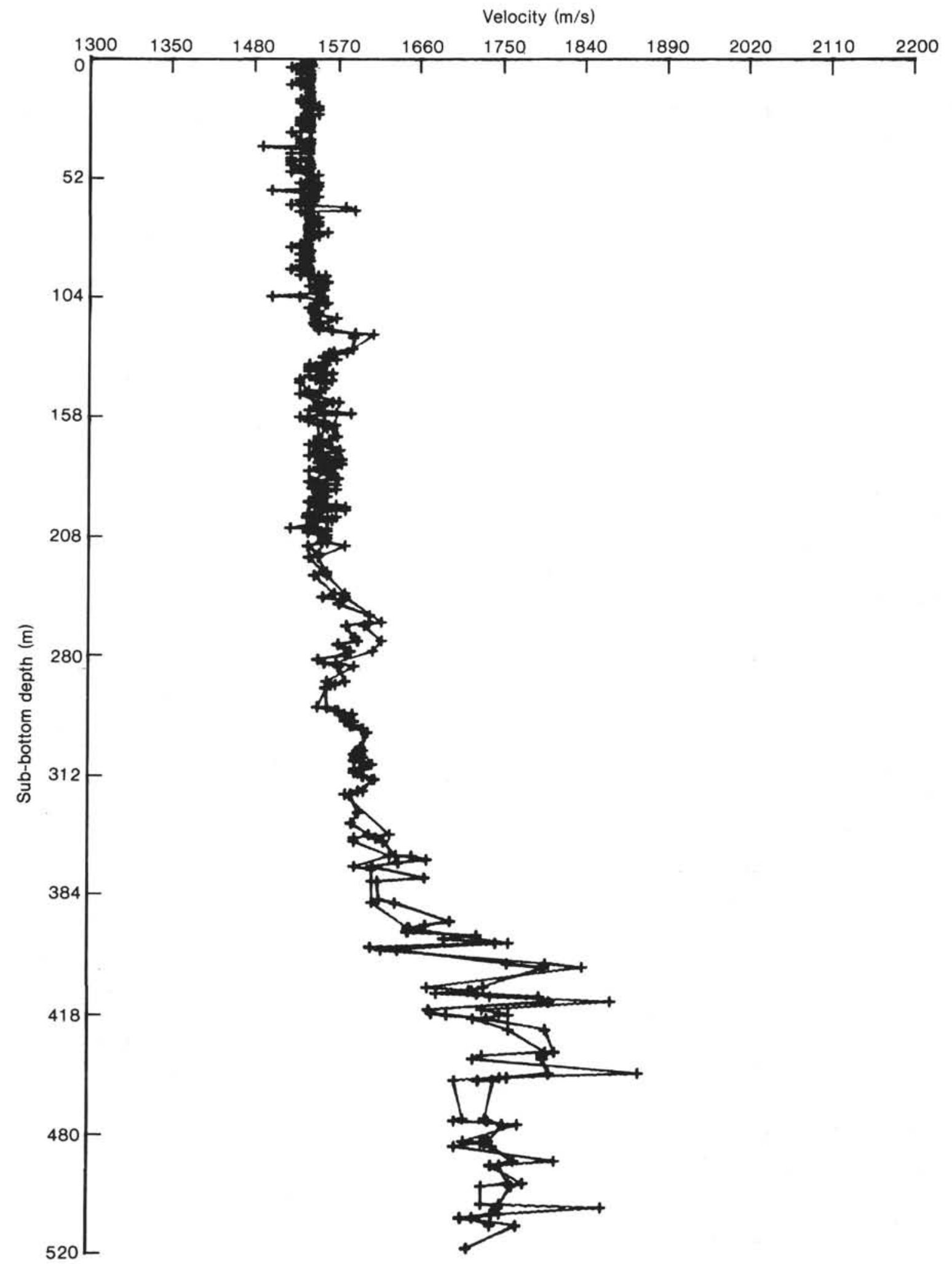

Figure 8. Predicted (from porosity) laboratory velocity versus sub-bottom depth and measured laboratory velocity versus subbottom depth, DSDP Site 574 . 


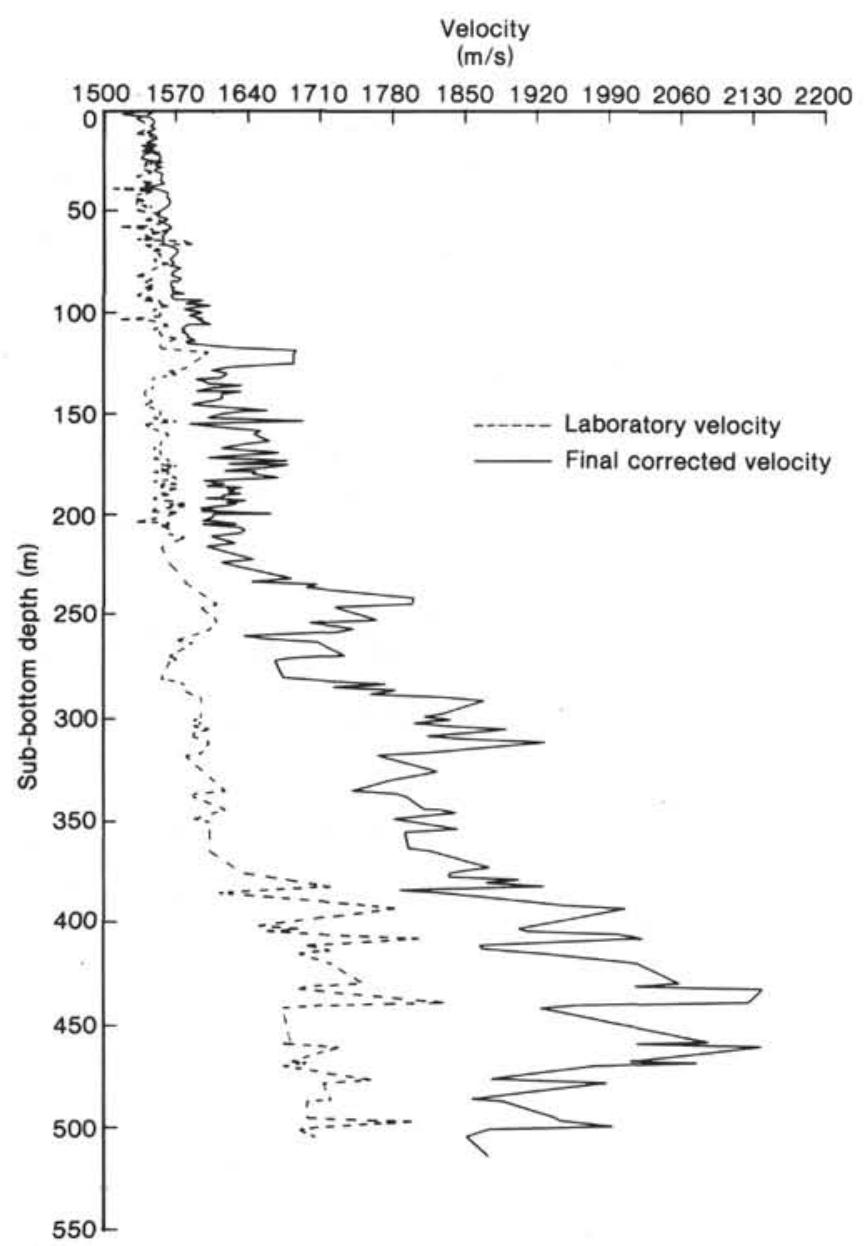

Figure 9. Laboratory velocity and final corrected velocity versus subbottom depth.

calculated for this sediment (Fig. 11) will minimize any effect of internal multiples, a study of the role of attenuation and internal multiples in this particular sequence is currently under way.

\section{Sources of Error}

In addition to the errors associated with the conversion of traveltime to depth, numerous other factors add to the uncertainty of correlating the field seismic profile with the synthetic seismogram. First, the seismic profile does not precisely cross the drill site. The synthetic is placed near the closest point of approach on the profile where it best matches the field record. The lateral variability in the position of the major reflectors within the survey area is greater than any of the field record/synthetic mismatches of reflector positions, and thus the uncertainty of the location of the drill site with respect to the profile may contribute to any error. Second, the source signature was not monitored on every shot; rather, a representative signature is used for the synthetics. If the source signature when the profile across the drill site was collected differs from the representative signature, the synthetic will certainly differ from the field record. Finally, some error is probably associated with the inconsistent picking of horizons, because reflectors merge

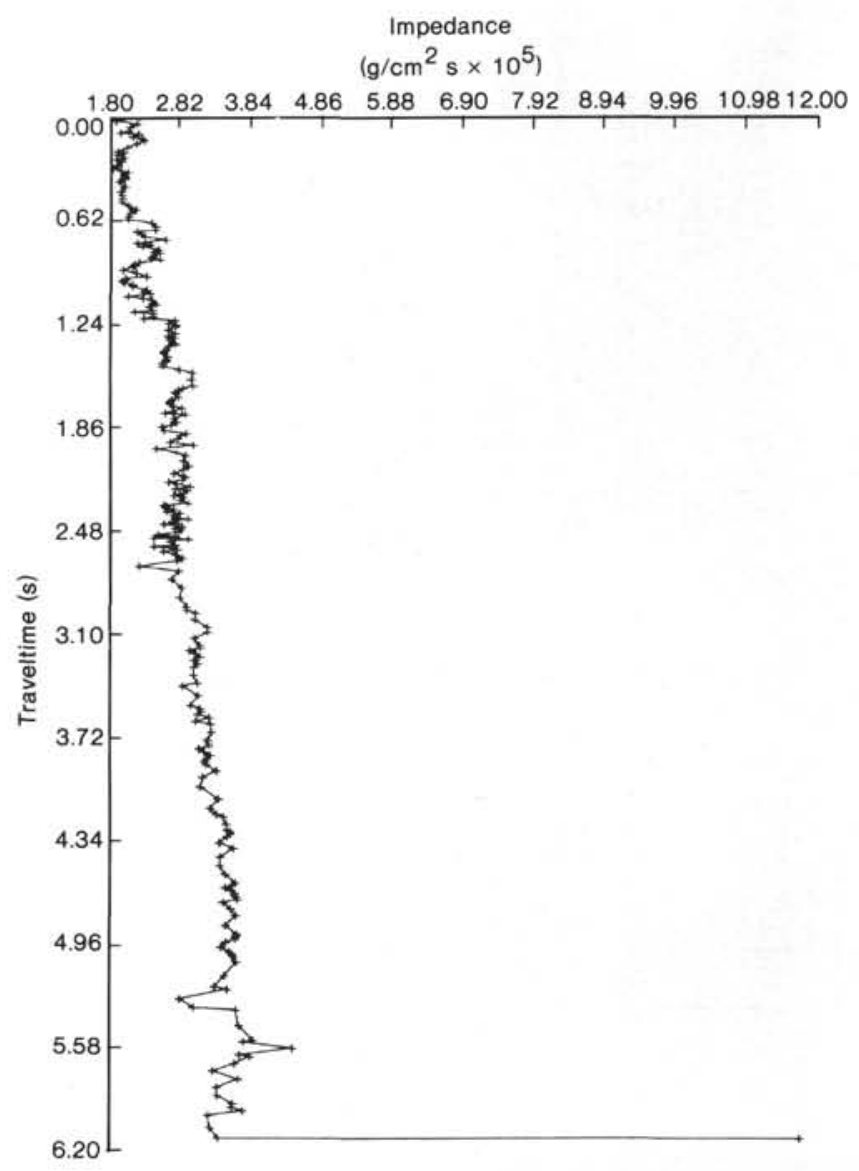

Figure 10. Impedance versus traveltime, DSDP Site 574.

and separate as a function of sedimentation rate. Clearly, the synthetic is not a perfect match of the field record; all of the foregoing factors probably contribute to this imperfect matching. For the purpose of stratigraphic correlation, the traveltime to a given reflector, as picked from the field record, is used in the calculated velocity function to yield a depth-in-hole. This maximizes the potential stratigraphic miscorrelation for a given reflector but eliminates the possibility that the wrong reflector is being used. Despite these uncertainties, the major reflectors are clearly identifiable on the synthetic seismogram, and their positions are correlatable with the field record within about $0.01 \mathrm{~s}$ (approximately $8 \mathrm{~m}$ ). This ability to correlate the synthetic with the field record suggests that we are not far off with our traveltimeto-depth conversion; and most important, it allows us to look at the measured downcore properties and determine precisely (within the limits of our resolution) where the reflectors occur.

\section{ORIGIN OF REFLECTORS}

Armed with an acceptable traveltime-to-depth conversion, we can now address the problem of the origin and geologic significance of the reflections. Our discussion is limited to the major traceable reflectors (those that have been assigned color names); the origin of the fine-scale reflection events will be addressed in future studies. Table 1 summarizes the traveltime picks of these 


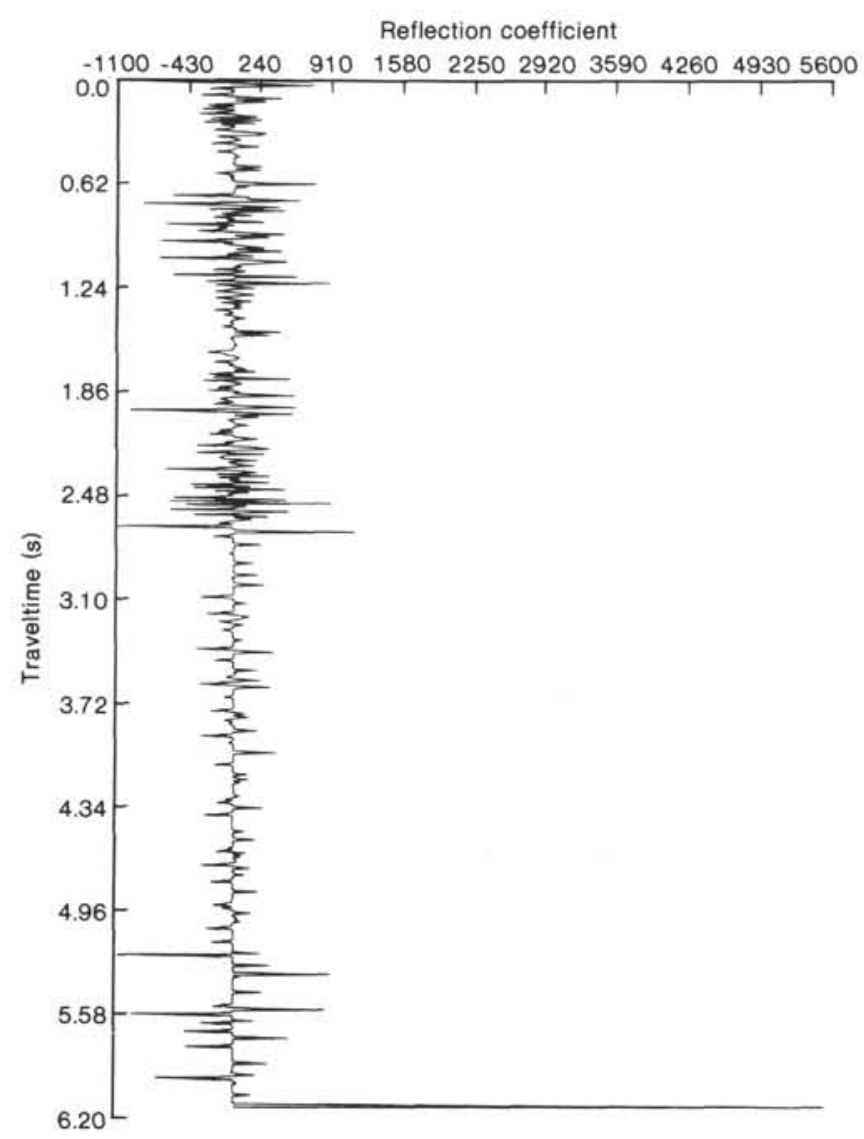

Figure 11. Reflection coefficient versus traveltime, DSDP Site 574.

reflectors from the field record and from the synthetic seismogram and reports the depths at which they occur as derived from our final corrected velocities.

The Site 574 impedance-versus-depth profile reveals that a significant shift or contrast in acoustic impedance is associated with each major reflector (Fig. 14). There are, however, numerous other large contrasts in impedance that are not associated with regionally correlatable reflectors (e.g., the impedance contrast at $121 \mathrm{~m}$ subbottom). To understand why some of these impedance contrasts result in regionally correlatable reflectors and others do not, we must take a closer look at the origin of the impedance contrasts. Impedance is the product of velocity and saturated bulk density. If we examine the relative contribution of each component by regressing velocity against impedance and density against impedance (Fig. 15), we see that there is an excellent correlation between density and impedance (Fig. 15A) but a poor linear correlation between velocity and impedance (Fig. 15B). The contrast can be explained by the relatively minor degree of fluctuation in sonic velocity (less than $6 \%$ of its mean value) and the significant degree of variation in saturated bulk density (more than $25 \%$ of its mean value). Thus, for the most part, the impedance curve is responding to fluctuations in saturated bulk density instead of velocity. To explain the changes in impedance, therefore, we need to understand the reasons for the changes in saturated bulk density.
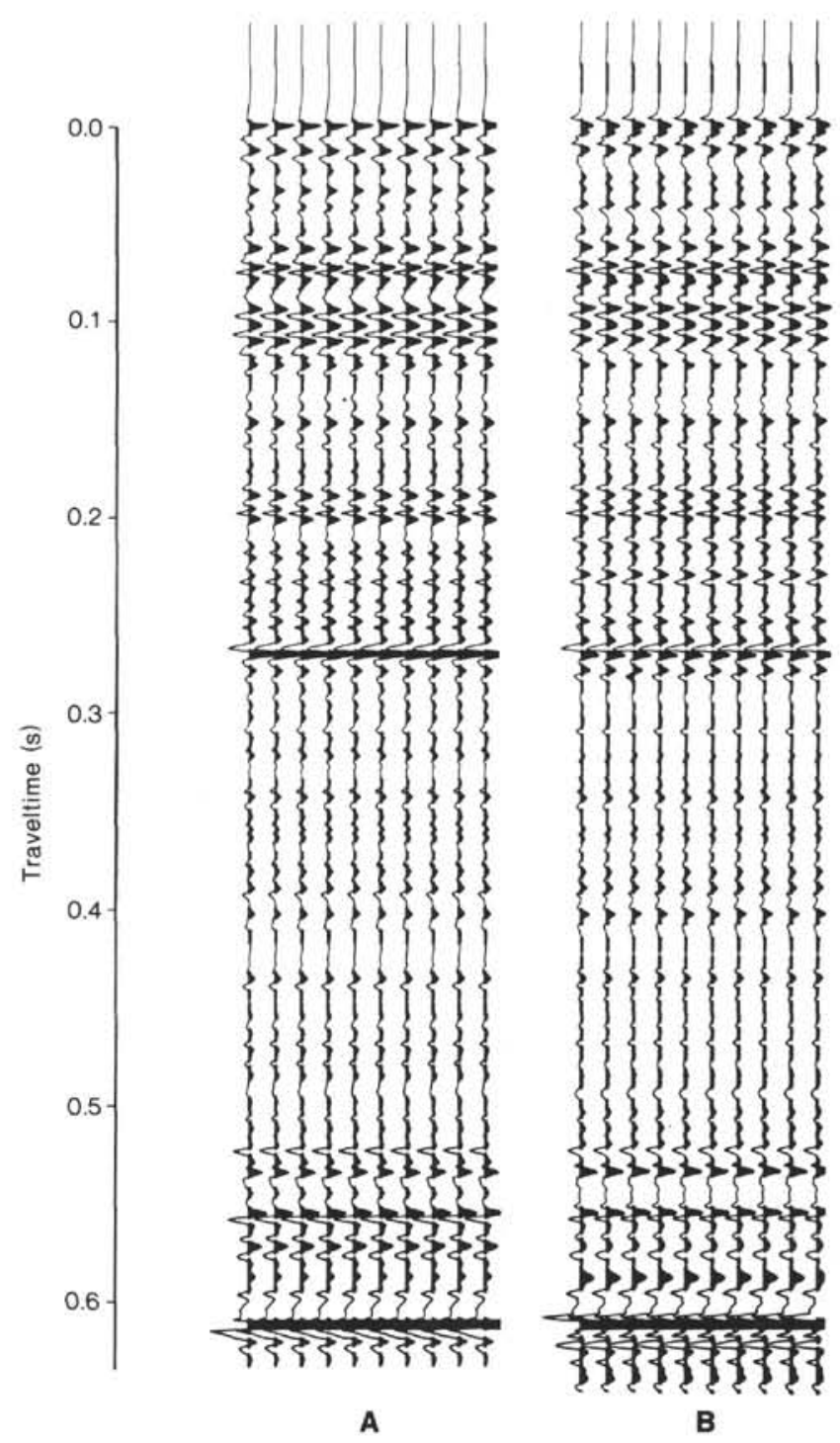

Figure 12. Calculated synthetic seismograms, DSDP Site 574. A. Deconvolved source signature. B. Raw source signature.

The dominant role of density in controlling the impedance curve (and thus the seismic profile) is evident when the positions of the major reflectors are marked on the density and velocity curves (Figs. 14B, C). All the major reflectors are associated with significant density contrasts, but only the deepest reflectors-Orange and Yellow-are associated with velocity contrasts. The cause of the density contrasts is clear when the carbonate curve (Fig. 14D) is compared with the density curve (Fig. 14C): a large change from high to extremely low carbonate values is associated with each of the major reflectors (except Yellow and Orange). In a detailed study of equatorial Pacific piston cores, Mayer (1979a) found a similar relationship and demonstrated that when the percentage of carbonate is low, the percentage of biogenic silica is very high, a composition that results in decreased saturated bulk density and thus decreased impedance. Thus, the Green, Brown, Purple, Red, and Lavender reflectors can be tied directly to major shifts in the carbonate con- 
tent of the sediment. The two deeper reflectors (Yellow and Orange) are associated with minor carbonate shifts and pose a more difficult problem. The velocity curve (Fig. 14B), however, reveals that these reflectors are correlated with velocity changes; examination of the core descriptions reveals that the first occurrence of chalk is recorded at the depth of the Yellow reflector and that numerous small indurated layers are associated with the Orange reflector. Thus, these deeper reflectors appear to represent diagenetic changes. There are numerous other velocity events, occurrences of chalk, and associated reflectors deeper in the section, but these reflectors are not regionally correlatable. We believe that this phenomenon is explained by the concept of diagenetic potential, which was first introduced by Schlanger and Douglas (1974); that is, that the processes responsible for the smaller changes in carbonate content and sediment induration at the Yellow and Orange reflectors were regional in extent, whereas the processes responsible for the other velocity contrasts were more local. A prime example of this is the large velocity offset associated with the reflector, not regionally correlatable, located at $121 \mathrm{~m}$ subbottom. A density and impedance change is associated with this velocity contrast, but there is no change in percent carbonate. The core descriptions at this interval reveal a large increase in the abundance of sand-sized material (i.e., foraminifers), which results in increases in velocity, density, and impedance and suggests localized winnowing or redeposition.

\section{AGE OF REFLECTORS}

The association of the major reflectors with carbonate or diagenetic events suggests that the seismic record in this region may indeed contain important and retrievable paleoceanographic information. To evaluate the paleoceanographic significance of these reflectors, we used the Leg 85 biostratigraphic results (Barron et al., this volume) to assign ages to the reflectors (Table 2).

A detailed study of the stratigraphic resolution obtainable on Leg 85 cores (Pisias et al., this volume) indicates that resolution varies with sedimentation rate but that for the closest sampling interval used, it can be taken to be approximately $4 \mathrm{~m}(125,000$ to 380,000 yr.). Because the resolution of our reflector correlations is less than this $( \pm 5 \mathrm{~m})$, we conservatively report the ages plus or minus $500,000 \mathrm{yr}$. A uniform time scale incorporating an Anomaly 5-Chron 9 correlation was used for all the Leg 85 analyses; but Barron et al. (this volume) propose an alternative middle to late Miocene time scale based on an Anomaly 5-Chron 11 correlation. This latter interpretation may prove to be more accurate, and we present alternative absolute ages based on this correlation in parentheses in Table 2. More detailed stratigraphic work may permit the further refinement of the absolute ages of the reflectors.

We have made similar analyses of Sites 573 and 575, and the ages of the regionally traceable reflectors are, within the limits of our resolution, identical to those determined for Site 574. Thus, the reflectors are essentially time surfaces; their association with carbonate or regional diagenetic events suggests that they are related to major changes in oceanographic parameters that operated over a large area and over a wide range of depths.

\section{PALEOCEANOGRAPHIC SIGNIFICANCE}

If, as we believe, the major traceable reflectors represent time surfaces associated with basinwide carbonate or diagenetic events, it becomes appropriate to attempt to identify these events and to assess their paleoceanographic significance. The speculations below are based on the identification (from Leg 85 results and previous studies) of significant changes in oceanographic parameters that took place at or near the same time as the seismic events. These correlations are general; the detailed biostratigraphic analyses necessary to establish precise relationships are beyond the scope of this study, but will, we hope, be the subject of future work.

\section{Orange and Yellow (20.5 to $22.5 \mathrm{Ma}$ )}

The Miocene was a time of critical climatic transition, and as such it has been the subject of numerous paleoceanographic studies (e.g., Savin et al., 1981, and references therein). Little detailed work has been done on the early Miocene; we are less confident of our correlation between reflectors $\mathrm{Y}$ and $\mathrm{O}$ and paleoceanographic events than we are for the younger horizons, but it is still possible to identify paleoceanographic events that may have been responsible for these reflectors. Vincent and Killingley (this volume) have identified eight levels within the middle and lower Miocene at which there are significant changes in the isotopic and carbonate record at the Leg 85 sites. The deepest of these two levels (events $\mathrm{A}$ and B; Vincent and Killingley, this volume) correlate well with the positions of the Orange and Yellow reflectors. These levels are marked by an increase in $\delta^{13} \mathrm{C}$ $(1.0 \%)$ for $\mathrm{A}$, a decrease in $\delta^{13} \mathrm{C}(0.2 \%)$ for $\mathrm{B}$, and an increase in the percent sand. In general, the interval between $\mathrm{A}$ and $\mathrm{B}$ is one of high $\delta^{13} \mathrm{C}$ values. Small changes in percent carbonate are associated with these levels, although the changes are nowhere near as large as those associated with the younger reflectors. As discussed earlier, the Orange and Yellow reflectors differ significantly from the younger ones in that they are associated with significant changes in velocity. We infer from this that they are diagenetic in origin, an inference supported by the presence of chalk and indurated layers at these depths. The coincidence of regionally traceable reflectors of diagenetic origin with the regional isotopic events described by Vincent and Killingley suggests the occurrence of significant oceanographic changes. Keller (1981) describes a major reorganization of planktonic foraminifers, marking the evolution of the highly diverse Neogene fauna, that took place during the early Miocene. This reorganization is linked to the development of the deep CircumAntarctic Current, which resulted from the opening of the Drake Passage by about $22.5 \mathrm{Ma}$ (Kennett et al., 1975 ), and to the establishment of steep thermal gradients between polar and tropical regions (Kennett, 1977; Keller, 1981). Although we cannot, at this point, draw specific links between the lower Miocene reflectors and identifiable oceanographic events (other than the isotopic shifts), we can speculate that the reorganization of the 


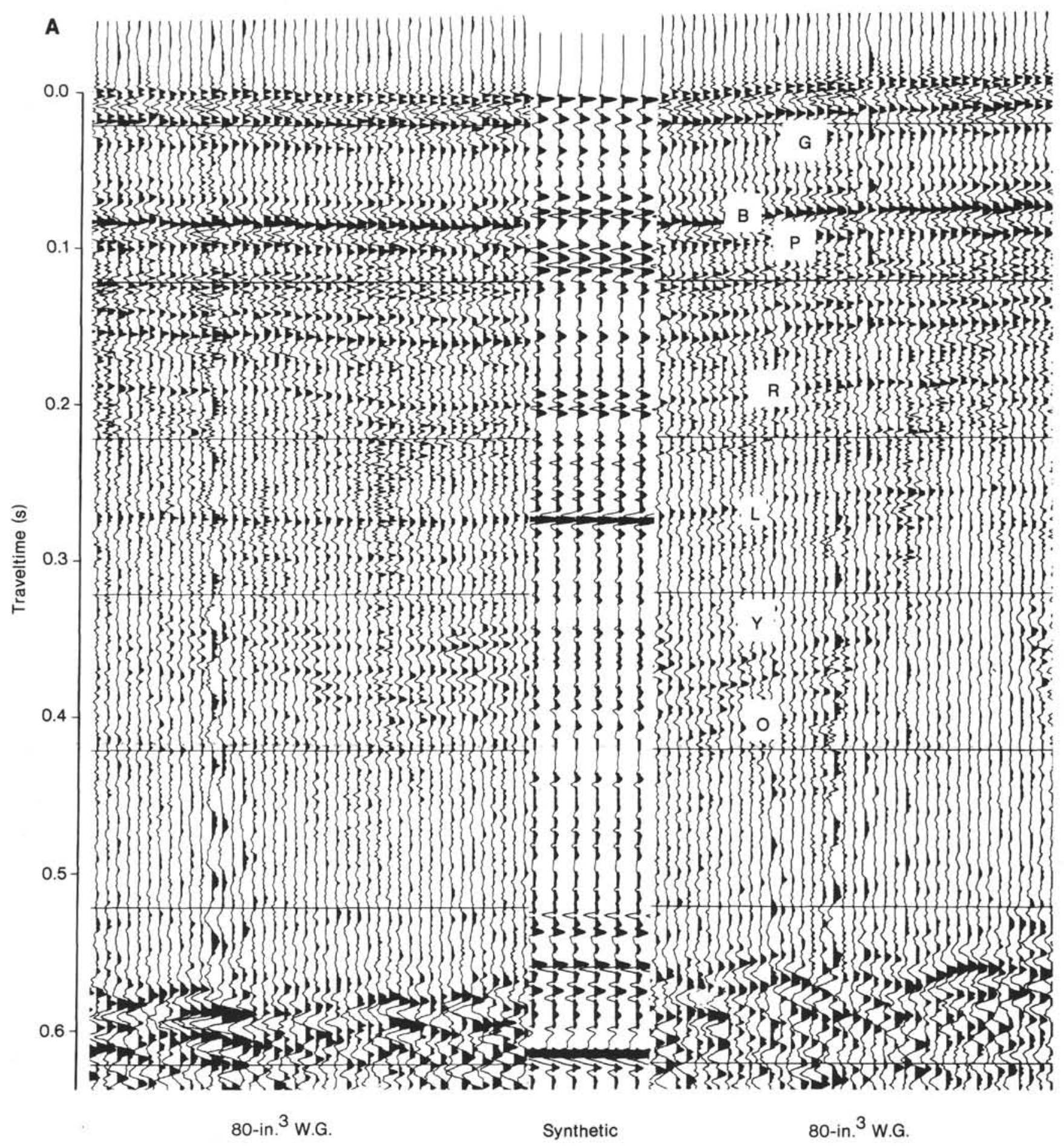

Figure 13. Comparisons of field data with synthetic seismograms. W.G. = field watergun record. A. Deconvolved source, no mix. B. Deconvolved source, 3-trace mix. C. Raw source, no mix. D. Raw source, 3-trace mix.

oceanic circulation system associated with the opening of Drake Passage resulted in changes in the chemistry of tropical Pacific waters that account for the isotopic shifts and the propensity of this material to indurate. The induration associated with this material accounts for the changes in velocity and saturated bulk density that result in the impedance contrasts responsible for the Orange and Yellow reflectors.

\section{Lavender (16 to $17 \mathrm{Ma}$ )}

There is an unequivocal association of the Lavender reflector with a major, sharp, early Miocene decrease in carbonate content that occurs at approximately $213 \mathrm{~m}$ sub-bottom (Fig. 14). This carbonate minimum has been reported previously (event $16 \mathrm{~g}$ of Dunn, 1982), and it is correlatable over much of the equatorial Pacific (Dunn, 


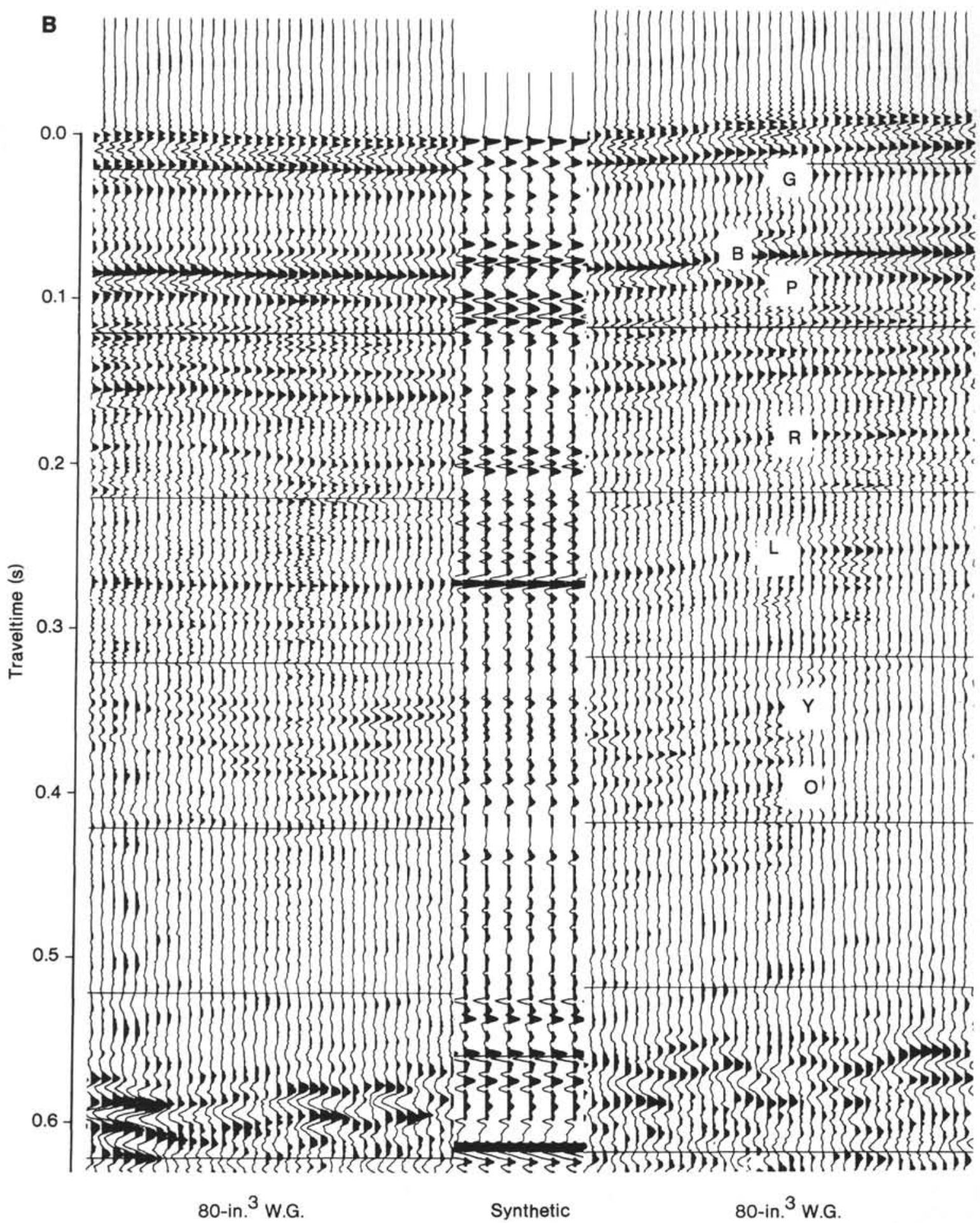

Figure 13. (Continued).

in press). Coincident with this carbonate minimum is the beginning of a marked enrichment (about 1\%o) in $\delta^{13} \mathrm{C}$-the level $\mathrm{E}$ event of Vincent and Killingley (this volume). This $\delta^{13} \mathrm{C}$ enrichment has been identified in numerous Indian Ocean cores and labeled the "Chron 16 carbon shift" by Vincent et al. (1983). The beginning of this shift predates the cessation of an early Miocene warming trend (event F of Vincent and Killingley, this volume), as seen in the $\delta^{18} \mathrm{O}$ signal (Savin et al., 1981), and it is attributed to the accumulation around the North Pacific margins of organic-carbon-rich sediments that preferentially extract ${ }^{12} \mathrm{C}$ from the ocean (Vincent et al., 1983). Also associated with this period is the occurrence of a widespread hiatus (NH2), which is interpreted as being the result of intensified bottom flow (Keller and Barron, 1983). Unlike the younger carbonate minima, 


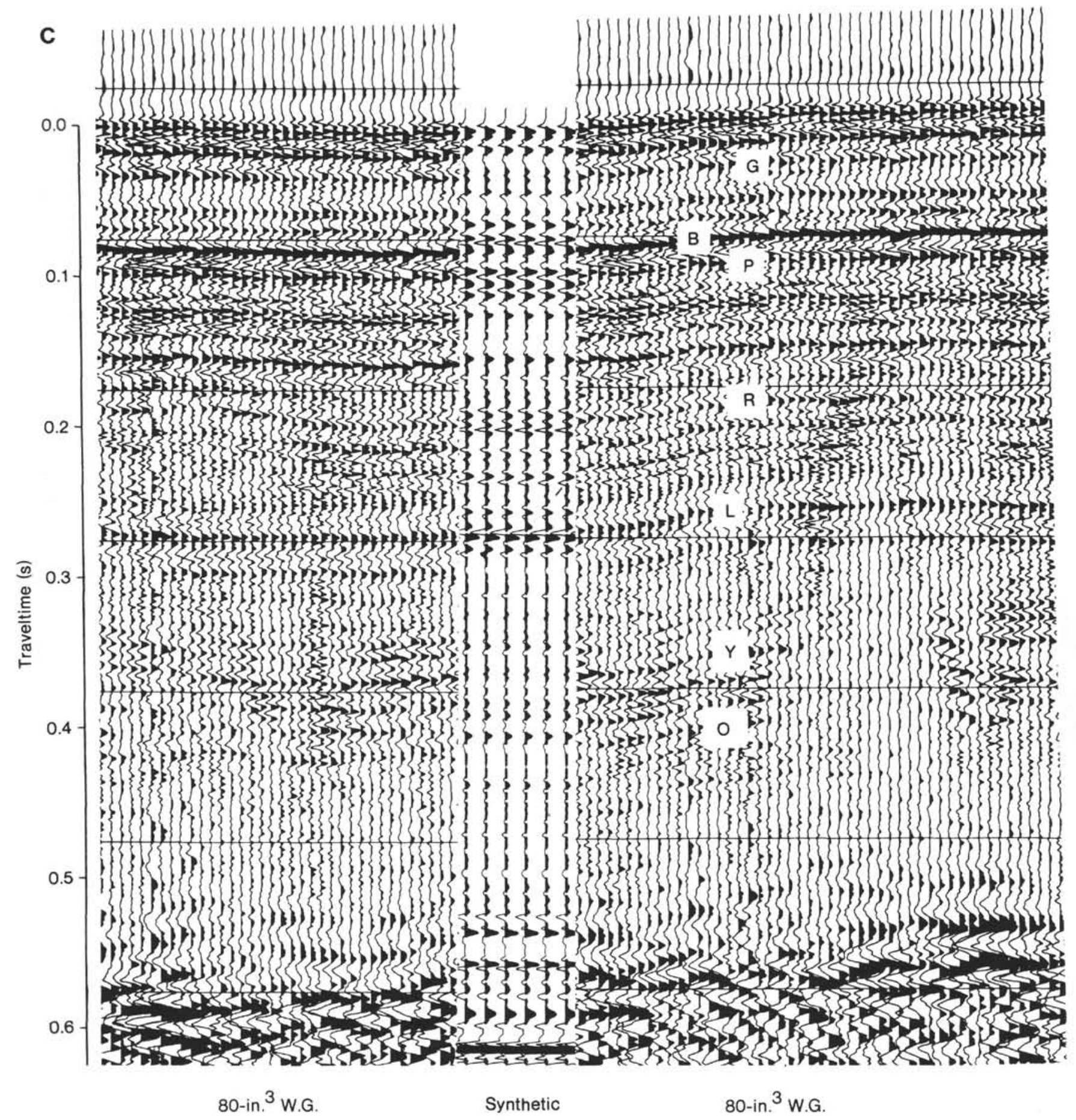

Figure 13. (Continued).

the "dissolution spike" associated with the Lavender reflector is not also associated with a $\delta^{18} \mathrm{O}$ enrichment (in fact, bottom waters at this time were the warmest of the Miocene; Savin et al., 1981), so the Lavender reflector is the only post-18 Ma reflector that is not correlated with an apparent climatic deterioration. Also coincident with the timing of the Lavender reflector are the onset of significant siliceous-ooze deposition in the equatorial $\mathrm{Pa}$ cific and North Pacific margins, a decline in the deposition of siliceous sediment in the North Atlantic (Keller and Barron, 1983), and a sharp rise and fall in eustatic sea level as determined by Vail and Hardenbol (1979).

The absence of climatic cooling, in association with a sharp decrease in carbonate content, tends to support the hypothesis of Keller and Barron (1983) that tectonic events (perhaps the closing of the Tethyan Seaway, uplift in Central America, and the sinking of the Iceland-Faroe Ridge), in concert with eustatic sea-level fluctuations, may ultimately have caused the changes in circulation patterns that resulted in the introduction or intensifica- 


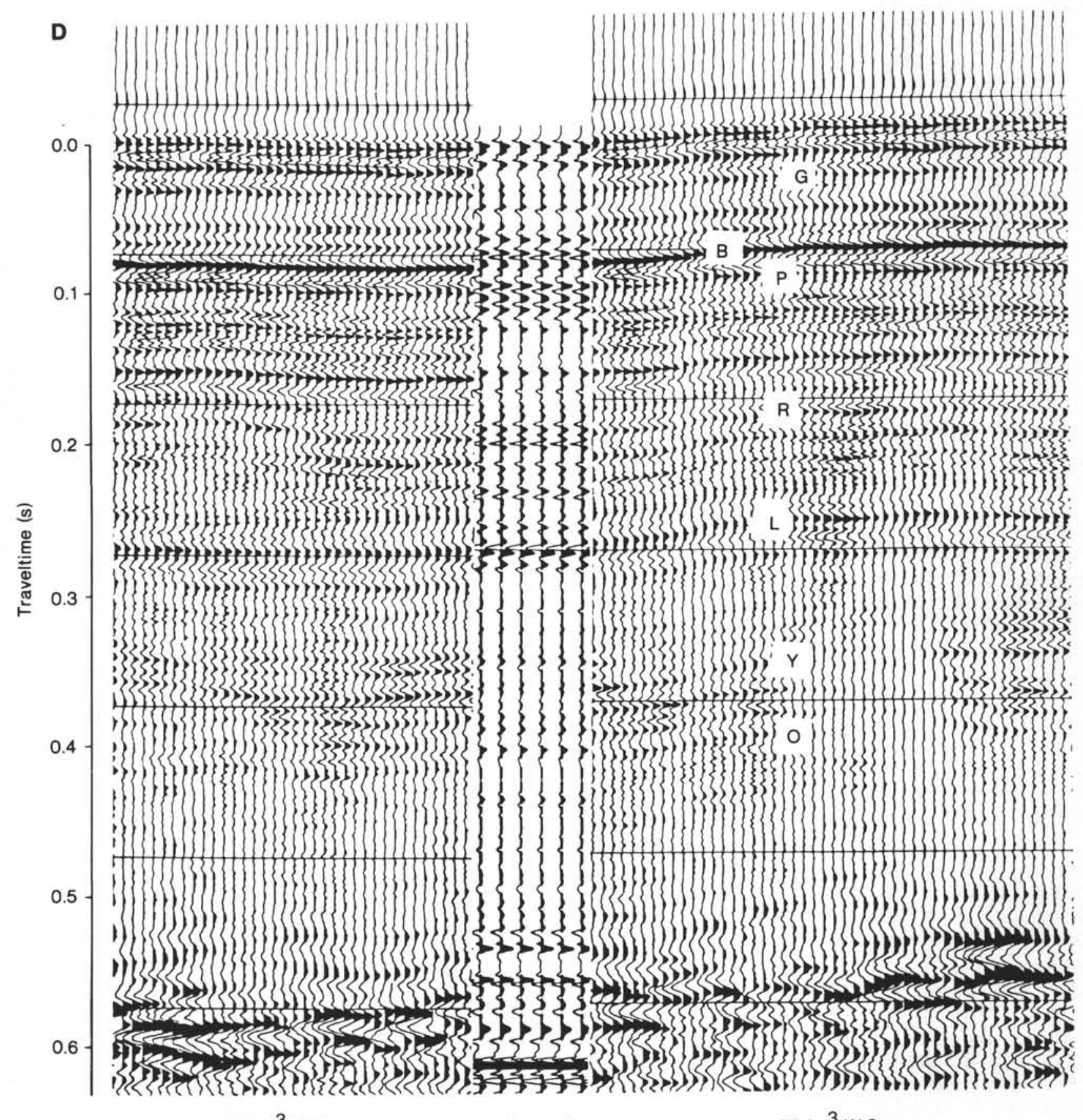

Figure 13. (Continued).

tion of Norwegian Overflow Water into the North Atlantic. This southward incursion of North Atlantic Deep Water decreased the amount of upwelling of Antarctic Bottom Water in the Atlantic and provided more of this silica-rich bottom water to the Pacific (Berger, 1970; Keller and Barron, 1983). The intensification of AABW circulation in the Pacific resulted in severe carbonate dissolution and thus the Lavender reflector. Increased upwelling of AABW in the equatorial Pacific and Pacific margins led to the rapid extraction of organic carbon from the ocean-atmosphere system and to the beginning of the "Monterey carbon excursion" of Vincent and Berger (in press), which may explain the onset of global cooling.

\section{Red (13.5 to 14.5 Ma)}

As with all of the pre-18 Ma reflectors, the impedance contrast associated with the Red reflector results from a carbonate minimum (Fig. 14). Once again, this carbonate minimum has been identified in other equatorial Pacific cores and shown to be regionally correlatable (event $15 \mathrm{c}$ of Dunn, in press). The timing of this 
Table 1. Traveltime to major reflectors as picked from field record and synthetic seismogram, Site 574.

\begin{tabular}{|c|c|c|c|}
\hline \multirow[b]{2}{*}{ Reflector } & \multicolumn{2}{|c|}{ Traveltime (s) } & \multirow{2}{*}{$\begin{array}{l}\text { Depth in } \\
\text { section }^{\mathrm{a}} \\
\text { (m) }\end{array}$} \\
\hline & $\begin{array}{l}\text { Field } \\
\text { record }\end{array}$ & Synthetic & \\
\hline Green & 0.03 & 0.031 & 24 \\
\hline Brown & 0.08 & $0.075-0.08$ & $58-62$ \\
\hline Purple & 0.098 & $0.093-0.103$ & $72-80$ \\
\hline Red & 0.193 & $0.188-0.195$ & $147-155$ \\
\hline Lavender & 0.267 & 0.268 & 213 \\
\hline Yellow & 0.365 & $0.362-0.367$ & $290-300$ \\
\hline Orange & 0.410 & 0.403 & $325-335$ \\
\hline Basement & 0.6025 & 0.611 & 520 \\
\hline
\end{tabular}

${ }^{\text {a }}$ Depth in section is depth calculated using the field record traveltime and the calculated velocity-versus-depth function.

event is coincident with the occurrence of a widespread hiatus (NH3; Keller and Barron, 1983), a major change (drop in sea level?) in the coastal-onlap curve of Vail and Hardenbol (1979), and significant changes in planktonic and benthic foraminiferal assemblages (Keller, 1980; Woodruff et al., 1981) as well as diatom assemblages (Barron, this volume). Significant changes in benthic faunas at Site 574 are not clearly associated with the increase in $\delta^{18} \mathrm{O}$, however (Thomas, this volume). More striking is the correspondence of this reflector with the very rapid increase in ${ }^{18} \mathrm{O}$ reported by Savin et al. (1975), Shackleton and Kennett (1975a and b), Savin et al. (1981), and Woodruff et al. (1981). This isotopic shift has been associated with high-latitude cooling and the buildup of ice on Antarctica, although Matthews and Poore (1980) argue for a drop in temperature of the deep waters rather than the substantial buildup in Antarctic ice.

An extremely detailed study (sample interval representing $3000 \mathrm{yr}$.) of the carbon, oxygen, and carbonate stratigraphy of the interval spanning the Red reflector was conducted by Pisias and Shackleton (this volume). They determined that the major $\delta^{18} \mathrm{O}$ shift (approximately $1 \% 0$ ) representing this oceanic event occurred in the remarkably short interval of $30,000 \mathrm{yr}$. and is recorded precisely (within the limits of our resolution) at the depth of the Red reflector $(155 \mathrm{~m})$. Pisias and Shackleton (this volume) use the high degree of variability in the isotopic record before this middle Miocene event to hypothesize significant variations in ice volume, although they acknowledge that a radically different deep-water structure before $14.5 \mathrm{Ma}$ could also explain the variability.

Thus, the increase in AABW associated with climatic degradation, and probably with the rapid buildup or increase in volume of Antarctic ice, resulted in increased carbonate dissolution and the Red reflector. It is interesting that the carbonate minimum associated with this major oceanic event is much less pronounced than that associated with the Lavender reflector (and the younger ones). We speculate that carbonate remains comparatively stable because no North Atlantic Deep Water event is associated with this time interval. When NADW becomes intensified, it forms a lid on AABW in the Atlantic (as with the Lavender, Purple, and Green reflectorssee discussion following); more, silica-rich AABW is put into the Pacific, and we see a fractionation of silica between the Atlantic and Pacific and an overall increase in upwelling, productivity, and silica deposition in the $\mathrm{Pa}$ cific. AABW during these times is particularly corrosive to carbonate, and extreme carbonate minima result. The Lavender event, however, is the response to just the intensification of AABW, and it results in a less extreme carbonate minimum.

\section{Purple (11 to $12 \mathrm{Ma}$ or 8.5 to $9.5 \mathrm{Ma}$ )}

The Purple reflector is associated with the most extreme of the carbonate minima (from 80 to $2 \% \mathrm{CaCO}_{3}$ ), a mechanism clearly likely to generate an impedance contrast. More significantly, this event marks a change in the style of carbonate deposition in the Pacific. Before the Purple event, carbonate values are generally high, with small-amplitude fluctuations (except for occasional events like Lavender); after Purple, there are large, highamplitude, high-frequency swings in carbonate content reminiscent of Pleistocene dissolution cycles. This shift in the style of carbonate deposition is also associated with a major sediment color change, and it marks a major lithologic boundary (cyclic siliceous calcareous ooze to calcareous ooze chalk-see Site 574 site chapter, this volume). As with the other carbonate minima, this event has been previously reported and correlated over a large area of the equatorial Pacific (mid-Epoch 10, Vincent, 1981). Associated with this event are a widespread hiatus (NH4, Keller and Barron, 1983), an increase in provincialism between low- and high-latitude planktonic microfossil assemblages (Barron, this volume; Bukry, this volume), and an apparent fall in eustatic sea level (Vail et al., 1977). Detailed isotopic analyses have not yet been performed on Leg 85 samples over this interval, but generalized equatorial Pacific isotope curves presented by Savin et al. (1981) and Woodruff et al. (1981) clearly show an enrichment (about $0.5 \% 0$ ) in $\delta^{18} \mathrm{O}$ at this time. Approximately coincident with this interval is a major erosional event that can be identified in North Atlantic seismic profiles (Mountain and Tucholke, 1983; Tucholke and Laine, 1982), which is interpreted as resulting from an intensification of North Atlantic bottom-water circulation. This event directly predates the onset of major drift deposition in the western North Atlantic.

The resulting paleoceanographic scenario is therefore similar to that described for reflector Lavender. An intensification of NADW (and an associated global cooling) resulted in the southward spread of NADW, causing decreased deposition of silica in the Atlantic and increased deposition of siliceous material in the Pacific (Keller and Barron, 1983). Intensified, highly corrosive $\mathrm{AABW}$ in the Pacific results in the carbonate minimum and the Purple reflector. The climatic degradation results in the intensification of the Equatorial Undercurrent system and the establishment of the steep latitudinal thermal gradients that have characterized the Pacific since this time (Barron, this volume).

\section{Brown (7 to $8 \mathrm{Ma}$ or 6.5 to $7.5 \mathrm{Ma}$ )}

The Brown reflector is more difficult to correlate with paleoceanographic events than the others. The reflector 


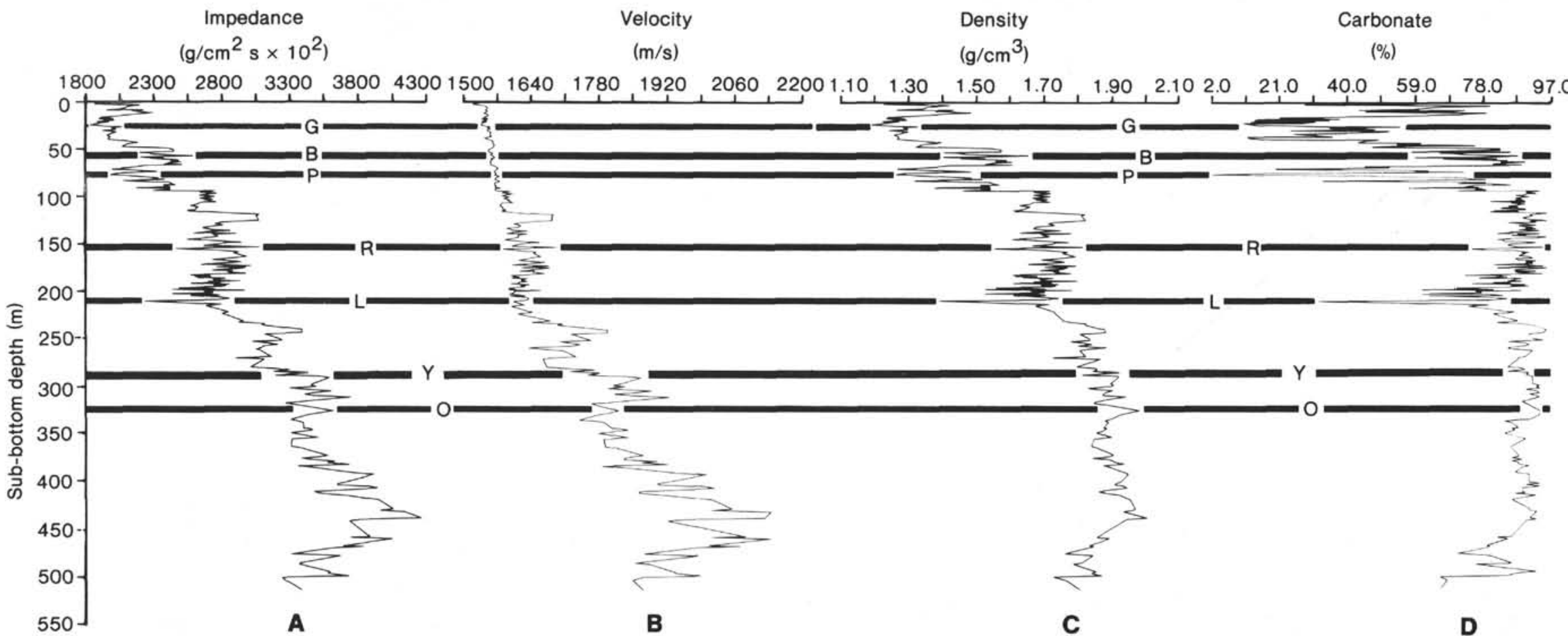

Figure 14. Correlation of major regional reflectors (G, B, P, R, L, Y, O) and physical properties at Site 574. A. Impedance versus sub-bottom depth, Site 574. B. Sonic velocity versus sub-bottom depth, Site 574. C. Saturated bulk density versus sub-bottom depth, Site 574. D. Percent carbonate versus sub-bottom depth, Site 574. 

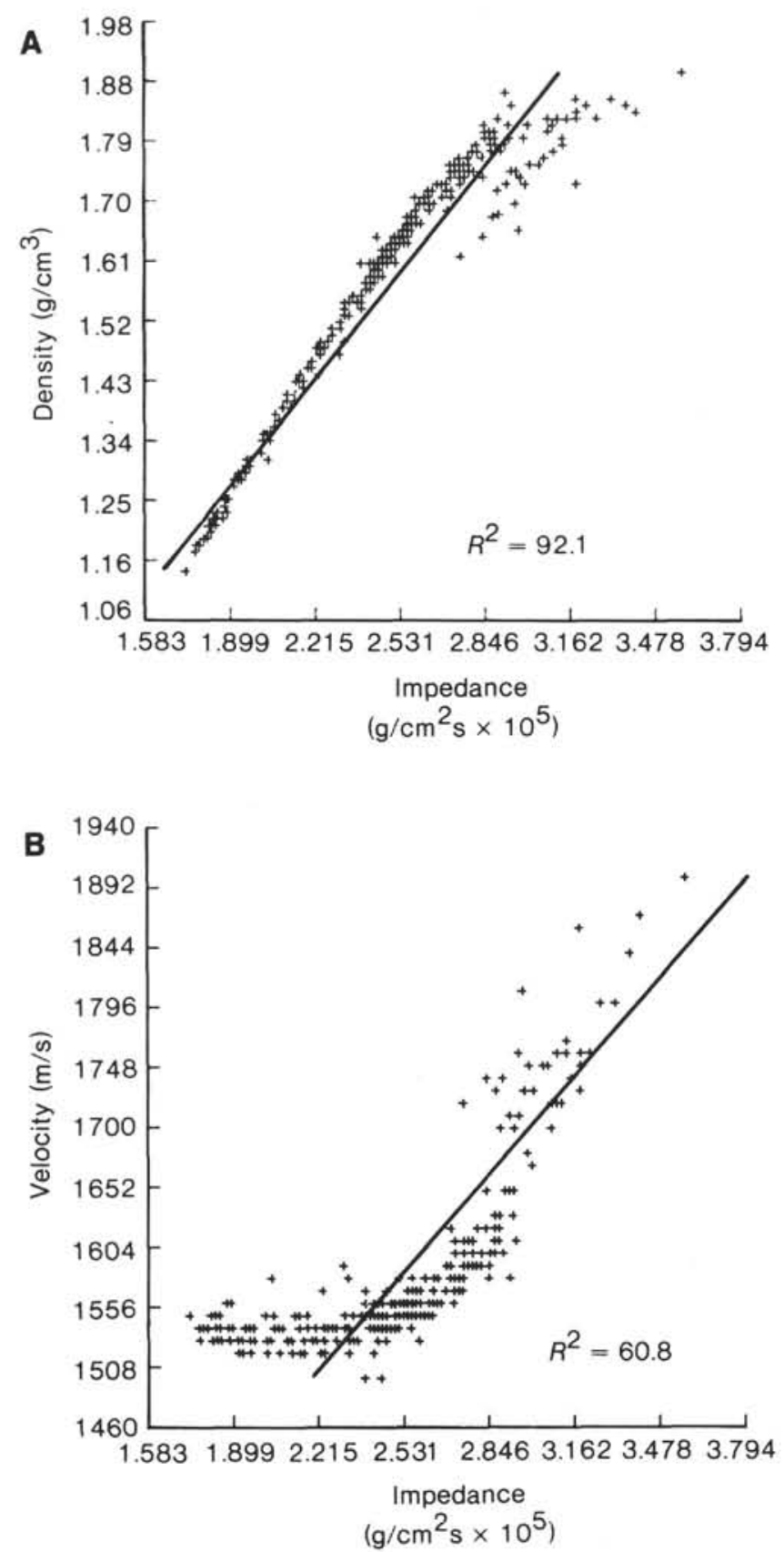

Figure 15. Correlation between density, velocity, and impedance. Solid line represents linear regression; $R^{2}=$ correlation coefficient. A. Regression of impedance against density, Site 574. B. Regression of impedance against velocity, Site 574.

does correlate with a small carbonate minimum, but this minimum is one of several in a region of generally high carbonate values (Fig. 14). These closely spaced carbonate fluctuations cause a complicated impedance structure that results in a complex reflector structure at this level on the synthetic seismogram (Fig. 13). It is just this sort of closely spaced structure that is most susceptible to interference effects, because small inaccuracies can result in miscorrelations.

In terms of paleoceanographic events, the Brown reflector is roughly coincident with a worldwide hiatus
(NH6, Keller and Barron, 1983), the onset of a permanent $\delta^{13} \mathrm{C}$ depletion (Keigwin, 1979; Vincent et al., 1980), a shoaling of the carbonate compensation depth (CCD) (van Andel et al., 1975), a major change in the relative sea-level curve (Vail et al., 1977), general climatic cooling (Woodruff et al., 1981), and a major faunal change in benthic foraminifers in the western Pacific (Woodruff and Douglas, 1981).

The constraints imposed by limited resolution are clearly evident when we look at the Brown reflector. The depthin-hole chosen for the Brown reflector on the basis of the field record is a few meters below a major carbonate shift. Close examination of the field seismic record (Fig. 13) reveals another reflector several meters above the Brown reflector that varies appreciably in amplitude over even the small lateral distance represented by this section. Despite the amplitude variations in the field record, the synthetic seismogram shows this reflector as a significant event $(0.061 \mathrm{~ms} ; 44$ to $48 \mathrm{~m}$ sub-bottom, Fig. 13). The major carbonate shift occurs at about the this same depth (Fig. 14). The carbonate shift is coincident with the regionally correlatable carbonate event (6e; Vincent, 1981), that is associated with the Epoch 6 carbon-isotopic depletion. A more detailed analysis of both the seismic section and the stratigraphic relationships will be necessary to resolve this problem.

\section{Green ( 3 to $4 \mathrm{Ma}$ )}

The youngest of our regionally correlatable reflectors (Green) presents few of the problems associated with the Brown reflector, despite the severe attenuation of this part of the section and the difficulty of distinguishing the Green reflector from the Magenta reflector (dated at 5 to $5.5 \mathrm{Ma}$ ), which is visible at the other Leg 85 sites. The Green reflector is clearly associated with a large carbonate minimum that results in a relatively large impedance contrast and can be tied into existing carbonate stratigraphies (Prell, this volume). Associated with the timing of this Pacific carbonate event is the major North Atlantic erosional event, which was followed by the onset of substantial turbidite deposition (Tucholke and Laine, 1982), an apparent eustatic sea-level drop (Vail et al., 1977), and a ubiquitous eastern Atlantic seismic reflection (J. Mienert, pers. comm., 1984).

We are tempted also to correlate the Green reflector with the initiation of Northern Hemisphere glaciation, as determined by ice-rafted sediments (Berggren, 1972) and $\delta^{18} \mathrm{O}$ trends (Shackleton and Kennett, 1975a; Shackleton and Opdyke, 1977; Keigwin, 1979). These studies report an enrichment in benthic $\delta^{18} \mathrm{O}$ of approximately $0.4 \%$ at about $3.2 \mathrm{Ma}$ and an association with the closing of the Isthmus of Panama. Prell (this volume), however, after looking at the detailed (5000-yr. sample interval) isotopic record from DSDP Site 572, argues that a steplike enrichment in $\delta^{18} \mathrm{O}$ is not found in the benthic record at 3.2 Ma (although a broad increase is found in the planktonic record). He infers from these data that, although a short ice growth may have occurred at this time, no permanent addition of ice volume was initiated. Instead, he postulates the establishment of colder bottom waters at this time, perhaps with an Antarctic 
Table 2. Sub-bottom depths, biostratigraphic zones, and ages for major reflectors at DSDP Site 574.

\begin{tabular}{|c|c|c|c|c|c|c|}
\hline & $\begin{array}{l}\text { Sub-bottom } \\
\text { depth } \\
\text { (m) }\end{array}$ & Foraminifers & $\begin{array}{l}\text { Calcareous } \\
\text { nannofossils }\end{array}$ & Radiolarians & Diatoms & Age $(\mathrm{Ma})^{\mathrm{a}}$ \\
\hline Green & 24 & N19 & CNII & Spongaster pentas & Nitzschia jouseae & $3-4$ \\
\hline Brown & $58-62$ & N17 & $\mathrm{CN} 8$ & $\begin{array}{l}\text { Didymocyrtis pentultiima/ } \\
\text { Didymocyrtis antepenultima }\end{array}$ & Nitzschia porteri & $7-8(6.5-7.5)$ \\
\hline Purple & $72-80$ & $\stackrel{?}{(\mathrm{~N} 16-\mathrm{N} 14)}$ & $\mathrm{CN} 7$ & Diartus petterssoni & Asteromphalus moronensis & $11-12(8.5-9.5)$ \\
\hline Red & $147-155$ & N10 & $\mathrm{CN} 4$ & Dorcadospyris alata & Coscinodiscus lewisiamus & $13.5-14.5$ \\
\hline Lavender & 213 & $\stackrel{?}{(\mathrm{~N} 8-\mathrm{N} 6)}$ & $\mathrm{CN} 3$ & Calocycletta costata & Denticula nicobarica & $16-17$ \\
\hline Yellow & $230-300$ & . $\mathrm{N} 4$ & $\mathrm{CN} 1$ & $\begin{array}{l}\text { Stichocorys delmontensis/ } \\
\text { Cyrtocapsella tetrapera }\end{array}$ & Rossiella paleacea & $20.5-21.5$ \\
\hline Orange & $325-335$ & N4 & $\mathrm{CN} 1$ & $\begin{array}{l}\text { Cyrtocapsella tetraperal } \\
\text { Lynchnocanoma elongata }\end{array}$ & Rocella gelida & $21.5-22.5$ \\
\hline
\end{tabular}

\footnotetext{
a Ages are based on Leg 85 time scale (see Introduction, this volume). Ages in parentheses represent alternative time scale using an Anomaly 5Chron 11 correlation (see Barron et al., this volume).
}

source (Prell, this volume). The seismic record cannot resolve this controversy; it can only indicate that a globally synchronous event (or series of events) took place that resulted in current-controlled sedimentation in the Atlantic and enhanced carbonate dissolution in the Pacific.

\section{CONCLUSIONS}

The combination of high-resolution seismic reflection profiles and continuous, nearly undisturbed cores produced by DSDP Leg 85 site surveys and drilling have presented us with a unique opportunity to examine the paleoceanographic significance of the seismic record. We have identified eight major, regionally traceable reflectors (labeled Orange, Yellow, Lavender, Red, Purple, Brown, Green, and Magenta) that can be traced around a $360,000-\mathrm{km}^{2}$ area of the central equatorial Pacific, bounded by the Clipperton and Galapagos fracture zones. The seismic section in this region is typical of that for pelagic carbonates; pelagic drape is the dominant geometry, but numerous erosional and slump features are also present. To examine the origin and paleoceanographic significance of the major, traceable reflectors, we have focused our study on DSDP Site 574, where seven of the eight reflectors are easy to identify and core recovery and core quality were excellent.

Essential to the geologic interpretation of the seismic record is the ability to transform the seismic information (a time-domain record) into a depth-domain record that can be directly compared with downhole stratigraphies. This transformation assumes accurate knowledge, not readily available, of the in situ velocity structure. We concentrated efforts on converting the laboratorydetermined velocity and density values to in situ values and made corrections for porosity rebound and changes in temperature and pressure. These corrections are significant ( 8 to $10 \%$ for the deepest samples); without them, the correlation of the seismic record with borehole results would be impossible. Synthetic seismogramsgenerated by using the corrected physical property values and a field-measured source signature-showed excellent agreement with the field records, suggesting that our traveltime-to-depth conversion is accurate and al- lowing us to determine precisely where in the cored section the reflectors occur (within the limits of our resolution $[ \pm 5 \mathrm{~m}])$.

The origins of the impedance contrasts responsible for the major traceable reflectors reveal that, for the most part, impedance contrasts are dominated by changes in saturated bulk density rather than velocity. All except the two oldest regionally traceable reflectors at Site $\mathbf{5 7 4}$ are associated with distinct density contrasts that correlate with carbonate minima. There are other strong reflectors in the section that are not regionally traceable. These reflectors, however, are not associated with carbonate minima, but correlate instead with velocity and grain-size contrasts. We interpret these reflectors as representing more local events, perhaps responses to localized winnowing and redeposition. Thus, in the younger part of the section, two distinct types of reflectors are present: those resulting from major, regionally traceable carbonate events, and those, caused by velocity contrasts, that are more local in their extent. In the deeper part of the section, most reflectors are associated with velocity contrasts and changes in induration. We conclude that the two regionally traceable reflectors in this part of the section result from basinwide events that caused more rapid induration of the sediment at these levels.

Comparison of the stratigraphic positions of the major regionally traceable reflectors with the Leg 85 time scale permits the assignment of ages $( \pm 500,000 \mathrm{yr}$.) to each of the reflectors. These ages are as follows: Orange, 21.5 to $22.5 \mathrm{Ma}$; Yellow, 20.5 to $21.5 \mathrm{Ma}$; Lavender, 16 to $17 \mathrm{Ma}$; Red, 13.5 to $14.5 \mathrm{Ma}$; Purple, 11 to $12 \mathrm{Ma}$; Brown, 7 to $8 \mathrm{Ma}$; and Green, 3 to $4 \mathrm{Ma}$. Similar analyses at the other Leg 85 sites reveal that, within the limits of our resolution, the ages of these reflectors are identical at all sites. Thus, the reflectors are time surfaces (at least within our study area), and their association with carbonate or diagenetic events suggests that they are related to major changes in ocean chemistry that operated over a wide range of depths.

The Orange and Yellow reflectors are associated with a marked increase in $\delta^{13} \mathrm{C}$, a major reorganization of planktonic foraminiferal assemblages, the development of the deep Circum-Antarctic Current, and the establish- 
ment of steep thermal gradients between tropical and polar regions. This reorganization of the oceanic circulation system was probably a response to the opening of the Drake Passage, and it resulted in changes in the chemistry of tropical Pacific waters that caused the induration (and thus the impedance contrasts) associated with these reflectors.

The Lavender reflector is associated with a large carbonate minimum, the "Chron 16 carbon shift," a widespread hiatus (NH2), major eustatic sea-level fluctuations, and a significant increase in silica deposition in the Pacific. Unlike the other reflectors, Lavender is not associated with a $\delta^{18} \mathrm{O}$ enrichment or climatic cooling. We conclude that this event represents intensification of AABW circulation and the partitioning of silica between the Atlantic and the Pacific, resulting from the introduction of NADW in response to tectonic events. Increased Pacific upwelling associated with intensified silica-rich AABW circulation may account for the beginning of the "Monterey carbon excursion" (Vincent and Berger, in press) and the onset of global cooling in the middle Miocene.

The Red reflector is associated with a subdued carbonate minimum, a widespread hiatus (NH3), a sea-level drop, significant changes in microfossil assemblages, and a major increase in $\delta^{18} \mathrm{O}$ that has been linked with the buildup or increase in volume of Antarctic ice. Detailed isotopic analyses (Pisias and Shackleton, this volume) reveal that this isotopic shift occurred within an interval of $30,000 \mathrm{yr}$. and precisely at the depth of the Red reflector.

The Purple reflector is associated with an extremely large carbonate minimum, a change in the style of carbonate deposition in the Pacific, a major lithologic boundary, a widespread hiatus (NH4), an increase in the provincialism between low and high latitudes in all planktonic microfossil assemblages, an apparent fall in eustatic sea level, an enrichment in $\delta^{18} \mathrm{O}$, and a major North Atlantic reflection interpreted as representing an intensification of North Atlantic bottom-water circulation. Once again we call upon the intensification of NADW, resulting in highly corrosive AABW, to account for the extreme carbonate dissolution in the Pacific and the Purple reflector.

The Brown reflector is associated with a small carbonate minimum, an enrichment in $\delta^{18} \mathrm{O}$, the late Miocene $\delta^{13} \mathrm{C}$ depletion, a drop in the relative sea-level curve, and faunal changes. A large carbonate minimum and a strong reflector that precisely correlate with the timing of the ${ }^{13} \mathrm{C}$ event are clearly seen on our synthetic seismograms a few meters above the Brown reflector. More detailed analyses of both the seismic section and stratigraphic relationships will be necessary to resolve this discrepancy.

The Green reflector is associated with a large carbonate minimum and with enrichment in $\delta^{18} \mathrm{O}$, a major western North Atlantic erosional event, and a ubiquitous eastern Atlantic seismic reflector. The bulk of evidence supports a correlation with the onset of Northern Hemisphere glaciation, but detailed isotopic analyses (Prell, this volume) indicate that this event may be linked to the establishment of colder bottom waters without major ice-sheet development.

In beginning this study, we set out to evaluate the potential of high-resolution seismic stratigraphy as a paleoceanographic tool in the central equatorial Pacific. We have been surprised by the impressive correlations that have resulted. We have seen that there are several types of reflectors in the equatorial Pacific. In the older (lower Miocene) section, reflectors resulted from diagenetic effects, and the regional reflectors were caused by global events. In the younger section (postdating lower Miocene), local reflectors are characterized by velocity contrasts, whereas regional reflectors are associated with density contrasts resulting from carbonate minima and global oceanographic changes. We have identified two modes for the generation of equatorial Pacific-wide carbonate minima and subsequent reflectors. The first mode calls for the intensification of AABW without concurrent intensification of NADW and without subsequent partitioning of silica between the Atlantic and the Pacific. This mode results in less extensive carbonate minima (the Red reflector). The second mode involves the intensification of AABW in response to the intensification of NADW and the associated enrichment of silica in the Pacific. This mode results in extreme carbonate minima and a correlation of Pacific reflectors with North Atlantic events (Lavender, Purple, Brown[?], and Green). Each of these types (local or regional, NADW-associated or not) is identifiable strictly from close study of the interrelationships among the physical properties responsible for the reflectors.

More important, we have established that careful analysis of the seismic record can be a powerful paleoceanographic tool. The results of this study will now permit us to trace identifiable, dated, synchronous events over large regions of the central equatorial Pacific. As the resolution of our profiling systems and stratigraphic analyses improves, our ability to link seismic features to paleoceanographic events will also improve (e.g., the result of very detailed sampling that correlates the Red reflector with a 30,000-yr. event), and the sometimes vague correlations we have established will become more precise. The seismic record is, by nature, the response to sharp contrasts. It is therefore an ideal tool for evaluating the already established "climatic steps" (Berger, 1982) in the Earth's history, and it may, in the future, provide a mechanism for identifying paleoceanographic events as yet undiscovered.

\section{REFERENCES}

Arrhenius, G., 1952. Sediment cores from the East Pacific. Rep. Swed. Deep Sea Exped. (1947-1948), 5:1-228.

Berger, W. H., 1970. Biogenous deep-sea sediments: fractionation by deep-sea circulation. Geol. Soc. Am. Bull., 81:1385-1402. 1973. Cenozoic sedimentation in the eastern tropical Pacific. Geol. Soc. Am. Bull., 84:1941-1954. 1982. Climate steps in ocean history-lessons from the Pleistocene. In Berger, W. H., Crowell, J. C., et al. (Eds.), Climate in Earth History, Studies in Geophysics: Washington (National Academy Press), pp. 43-53.

Berger, W. H., and Heath, G. R., 1968. Vertical mixing in pelagic sediments. J. Mar. Res., 26(2):134-143. 
Berger, W. H., Johnson, T. C., and Hamilton, E. L., 1977. Sedimentation on Ontong Java Plateau: observations on a classic "carbonate monitor." In Anderson, N. R., and Malahoff, A. (Eds.), The Fate of Fossil Fuel $\mathrm{CO}_{2}$ in the Oceans: New York (Plenum Press), pp. 543-567.

Berger, W. H., and Killingley, J., 1982. Box cores from the equatorial Pacific: ${ }^{14} \mathrm{C}$ sedimentation rates and benthic mixing. Mar. Geol., 45:93-126.

Berger, W. H., and Mayer, L. A., 1978. Deep sea carbonates: acoustic reflectors and lysocline fluctuations. Geology, 6:11-15.

Berggren, W. A., 1972. Late Pliocene-Pleistocene glaciation. In Laughton, A. S., Berggren, W. A., et al., Init. Repts. DSDP, 12: Washington (U.S. Govt. Printing Office), 953-963.

Boyce, R. E., 1976. Sound velocity-density parameters of sediment and rock from DSDP Drill Sites 315-318 on the Line Island Chain, Manihiki Plateau, and Tuamotu Ridge in the Pacific Ocean. In Schlanger, S. O., Jackson, E. D., et al., Init. Repts. DSDP, 33: Washington (U.S. Govt. Printing Office), 695-728.

Brown, L. F., and Fisher, W. L., 1977. Seismic stratigraphic interpretation of depositional systems: examples from Brazilian rift and pull-apart basins. In Payton, C. E. (Ed.), Seismic StratigraphyApplications to Hydrocarbon Exploration. Mem. Am. Assoc. Pet. Geol., 26:213-248.

CLIMAP, 1976. The surface of the Ice Age Earth. Science, 191: 1131-1137.

Crowe, J., 1981. Mechanisms of heat transport through the floor of the equatorial Pacific Ocean [Ph.D. dissert.]. Mass. Inst. Technol., Cambridge.

Dunn, D. A., 1982. Miocene sediments of the equatorial Pacific Ocean: carbonate stratigraphy and dissolution history [Ph. D. dissert]. Univ. Rhode Island, Narragansett.

in press. Early to middle Miocene carbonate stratigraphy and correlations of Pacific DSDP sites. In Kennett, J. P. (Ed.), The Miocene Ocean: Paleoceanography and Biogeography. Mem. Geol. Soc. Am.

Ewing, J., Ewing, M., Aitken, T., and Ludwig, W. J., 1968. North Pacific sediment layers measured by seismic profiling. In Knopoff, L., Drake, C. L., and Hart, P.J. (Eds.), The Crust and Upper Mantle of the Pacific Area. Am. Geophys. Union Geophys. Monograph, 12:147-186.

Geally, E. L., and Gerard, R. D., 1970. In situ petrophysical measurements in the Caribbean. In Bader, R. G., Gerard, R. D., et al., Init. Repts. DSDP, 4: Washington (U.S. Govt. Printing Office), 267-294.

Hamilton, E. L., 1965. Sound speed and related physical properties of sediments from Experimental Mohole (Guadalupe Site). Geophysics, 30(2):257-261.

1976. Variations of density and porosity with depth in deep sea sediments. J. Sediment. Petrol., 46(2):280-300.

1979. Sound velocity gradients in marine sediments. $J$. Acoust. Soc. Am., 65(4):909-922.

Hays, J. D., Cook, Harry E., III, Jenkins, D. G., Cook, F. M., Fuller, J. T., et al., 1972. Site 77. In Hays, J. D., et al., Init. Repts. DSDP, 9: Washington (U.S. Govt. Printing Office), 43-208.

Hays, J. D., Saito, T., Opdyke, N. D., and Burckle, L. H., 1969. Pliocene-Pleistocene sediments of the Equatorial Pacific: their paleomagnetic, biostratigraphic, and climatic record. Geol. Soc. Am. Bull., 80:1481-1514.

Houtz, R. E.,' and Ludwig, W. J., 1979. Distribution of reverberant subbottom layers in southwest Pacific Basin. J. Geophys. Res., 84: 3497-3504.

Hughes, D. S., and Cross, J. H., 1951. Elastic wave velocity in rocks at high pressures and temperatures. Geophysics, 16:577.

Johnson, T. C., Hamilton, E. L., Bachman, R. T., and Berger, W. H., 1978. Sound velocities in calcareous oozes and chalks from sonobuoy data: Ontong Java Plateau, western equatorial Pacific. $J$. Geophys. Res., 83:283-288.

Keigwin, L. D., Jr., 1979. Late Cenozoic stable isotope stratigraphy and paleoceanography from the east equatorial and north central Pacific Ocean. Earth Planet. Sci. Lett., 45:361-382.

Keller, G., 1980. Middle to late Miocene planktonic foraminiferal datum levels and paleoceanography of the North and southeastern Pacific Ocean. Mar. Micropaleontol., 5:249-281.
1981. Miocene biochronology and paleoceanography of the North Pacific. Mar. Micropaleontol., 6:535-551.

Keller, G., and Barron, J. A., 1983. Paleoceanographic implications of Miocene deep-sea hiatuses. Geol. Soc. Am. Bull., 94:590-613.

Kennett, J. P., 1977. Cenozoic evolution of Antarctic glaciation, the circum-Antarctic Ocean and their impact on global paleoceanography. J. Geophys. Res., 82:3843-3859.

in press. The Miocene ocean: paleoceanography and biogeography. Mem. Geol. Soc. Am.

Kennett, J. P., Houtz, R. E., Andrews, P. B., Edwards, A. R., Gostin, V. A., et al., 1975. Cenozoic paleoceanography in the southwest Pacific Ocean, Antarctic glaciation, and the development of the Circum-Antarctic Current. In Kennett, J. P., Houtz, R. E., et al., Init. Repts. DSDP, 29: Washington (U.S. Govt. Printing Office), $1155-1170$.

Kroenke, L. W., 1972. Geology of the Ontong Java Plateau [Ph.D. dissert.]. Hawaii Inst. Geophys., Honolulu.

Laughton, A. S., 1957. Sound propagation in compacted ocean sediments. Geophysics, 22:223-260.

Leinen, M., 1979. Biogenic silica accumulation in the central equatorial Pacific and implications for Cenozoic paleoceanography. Geol. Soc. Am. Bull., 90:1310-1376.

Luz, B., 1973. Stratigraphic and paleoclimate analysis of Pleistocene tropical southeast Pacific cores. Quat. Res., 3(1):56-72.

Matthews, R. K., and Poore, R. Z., 1980. Tertiary ${ }^{18} \mathrm{O}$ record and glacioeustatic sea-level fluctuations. Geology, 8:501-504.

Mayer, L. A., 1979a. Deep sea carbonates: acoustic, physical, and stratigraphic properties. J. Sediment. Petrol., 49(3):0819-0836. $1979 \mathrm{~b}$. The origin of fine scale acoustic stratigraphy in deepsea carbonates. J. Geophys. Res., 84(B11):6177-6184. 1982. Physical properties of sediment recovered on Deep Sea Drilling Project Leg 68 with the hydraulic piston corer. In Prell, W. L., Gardner, J. V., et al., Init. Repts. DSDP, 68: Washington (U.S. Govt. Printing Office), 365-382.

Mountain, G. S., and Tucholke, B. E., 1983. Abyssal sediment waves. In Bally, A. W. (Ed.), Seismic Expressions of Structural Styles. Stud. Geol. (Tulsa, Okla.) 15.

Savin, S. M., Douglas, R. G., Keller, G., Killingley, J., Shaughnessy, L., et al., 1981. Miocene benthic foraminiferal isotope records: a synthesis. Mar. Micropaleontol., 6:423-450.

Savin, S. M., Douglas, R. G., and Stehli, F. G., 1975. Tertiary marine paleotemperatures. Geol. Soc. Am. Bull., 86:1495-1510.

Schlanger, S. O., and Douglas, R. G., 1974. The pelagic ooze-chalklimestone transition and its implications for marine stratigraphy. In Hsü, K. J., and Jenkyns, H. C. (Eds.), Pelagic Sediments on Land and under the Sea. Spec. Publ. Int. Assoc. Sedimentol., 1: 117-148.

Shackleton, N. J., and Kennett, J. P., 1975a. Late Cenozoic oxygen and carbon isotopic changes at DSDP Site 284: implications for glacial history of the Northern Hemisphere and Antarctic. In Kennett, J. P., Houtz, R. E., et al., Init. Repts. DSDP, 29: Washington (U.S. Govt. Printing Office), 801-807.

1975b. Paleotemperature history of the Cenozoic and the initiation of Antarctic glaciation: oxygen and carbon isotope analyses in DSDP Sites 277, 279, and 281. In Kennett, J. P., Houtz, R. E., et al., Init. Repts. DSDP, 29: Washington (U.S. Govt. Printing Office), 743-755.

Shackleton, N. J., and Opdyke, W. D., 1973. Oxygen isotope and paleomagnetic stratigraphy of equatorial Pacific Core V28-238: oxygen isotope temperatures and ice volume on $10^{5}$ year and $10^{6}$ year scale. Quat. Res., 3:39-55.

1976. Oxygen isotope and paleomagnetic stratigraphy of $\mathrm{Pa}$ cific Core V28-239: late Pliocene to latest Pleistocene. Mem. Geol. Soc. $A m ., 145: 449-464$.

1977. Oxygen isotope and paleomagnetic evidence,for early Northern Hemisphere glaciation. Nature, 270:216-219.

Sheridan, R. E., Bates, L. G., Shipley, T. H., and Crosby, J. T., 1983. Seismic stratigraphy in the Blake-Bahama Basin and the origin of Horizon D. In Sheridan, R. E., Gradstein, F. M., et al., Init. Repts. $D S D P, 76:$ Washington (U.S. Govt. Printing Office), 667-683.

Shipley, T. H., 1983. Physical properties, synthetic seismograms, and seismic reflections: correlations at Deep Sea Drilling Project Site 534, Blake-Bahama Basin. In Sheridan, R. E., Gradstein, F. M., 


\section{A. MAYER ET AL.}

et al., Init. Repts. DSDP, 76: Washington (U.S. Govt. Printing Office), 653-666.

Shipley, T. H., Buffler, R. T., and Watkins, J. S., 1978. Seismic stratigraphy and geologic history of the Blake Plateau and adjacent western Atlantic continental margins. Am. Assoc. Petrol. Geol., 62:792-812.

Shipley, T. H., Winterer, E. L., and Lonsdale, P. F., 1983. Seismic stratigraphic analysis in the pelagic environment: the central Hess Rise, northwest Pacific. Mar. Geol., 51:47-62.

Tracey, J. I., Jr., Sutton, G. H., et al., 1971. Init. Repts. DSDP, 8: Washington (U.S. Govt. Printing Office).

Tucholke, B. E., 1979. Relationships between acoustic stratigraphy and lithostratigraphy in western N. Atlantic basin. In Tucholke, B. E., Vogt, P. R., et al., Init. Repts. DSDP, 43: Washington (U.S. Govt. Printing Office), 827-846.

Tucholke, B. E., and Laine, E. P., 1982. Neogene and Quaternary development of the lower continental rise off the central U.S. east coast. In Watkins, J. S., and Drake, C. L. (Eds.), Studies in Continental Margin Geology. Mem. Am. Assoc. Petrol. Geol., 34: 295-307.

Tucholke, B. E., and Mountain, G. S., 1979. Seismic stratigraphy, lithostratigraphy, and paleosedimentation patterns in the western North Atlantic. Am. Geophys. Union, Maurice Ewing Ser., 3:58-86.

U.S. Naval Oceanographic Office, 1962. Tables of Sound Speed in Seawater. U.S. Navoceano Spec. Publ. 58.

Vail, P. R., and Hardenbol, J., 1979. Sea level changes during the Tertiary. Oceanus, 22(3):71-80.

Vail, P. R., Mitchum, R. M., Todd, R. G., Widmier, J. M., Thompson, S., et al., 1977. Seismic stratigraphy and global changes in sea level. In Payton, C. E. (Ed.), Seismic Stratigraphy, Applications to Hydrocarbon Exploration. Mem. Am. Assoc. Petrol. Geol., 26: 49-205.

van Andel, T. H., Heath, G. R., et al., 1973. Init. Repts. DSDP, 16: Washington (U.S. Govt. Printing Office).

van Andel, T. H., Heath, G. R., and Moore, T. C., 1975. Cenozoic tectonics, sedimentation, and paleoceanography of the central equatorial Pacific. Mem. Geol. Soc. Am. 143.
Vincent, E., 1981. Neogene carbonate stratigraphy of Hess Rise (central North Pacific), and paleoceanographic implications. In Thiede, J., Vallier, T. L., et al., Init. Repts. DSDP, 62: Washington (U.S. Govt. Printing Office), 571-606.

Vincent, E., and Berger, W. H., in press. Carbon dioxide and polar cooling in the Miocene: the Monterey Hypothesis. In Sundquist, E. T., and Broecker, W. (Eds.), Chapman Conf. on Natural Variations in Carbon Dioxide and the Carbon Cycle. Am. Geophys. Union Monogr. Ser.

Vincent, E., Killingley, J. S, and Berger, W. H., 1980. The Magnetic Epoch-6 carbon shift: a change in the ocean's ${ }^{13} \mathrm{C} /{ }^{12} \mathrm{C}$ ratio 6.2 million years ago. Mar. Micropaleontol., 5:185-205.

1983. The Chron-16 carbon event in the Miocene Indian Ocean. Geol. Soc. Am. Abstr. Prog., 15:712. (Abstract)

Wilson, W. D., 1960. Speed of sound in seawater as a function of temperature, pressure, and salinity. J. Acoust. Soc. Am., 32(6): 641-644.

Winterer, E. L., 1973. Sedimentary facies and plate tectonics of the equatorial Pacific. Am. Assoc. Petrol. Geol. Bull., 57:265-282.

Winterer, E. L., Lonsdale, R. F., Matthews, J. L., and Rosendahl, B. R., 1974. Structure and acoustic stratigraphy of the Manihiki Plateau. Deep Sea Res., 21:793-814.

Winterer, E. L., Riedel, W. R., et al., 1971. Init. Repts. DSDP, 7: Washington (U.S. Govt. Printing Office).

Woodruff, F., and Douglas, R. G., 1981. Response of deep sea benthic foraminifera to Miocene paleoclimatic events, DSDP Site 289. Mar. Micropaleontol., 6:617-632.

Woodruff, F., Savin, S. M., and Douglas, R. G., 1981. Miocene stable isotope record: a detailed deep Pacific Ocean study and its paleoclimatic implications. Science, 212:665-668.

Date of Initial Receipt: 10 October 1984

Date of Acceptance: 29 January 1985 